\title{
Hydrologic modeling: progress and future directions
}

\author{
Vijay P. Singh*
}

\begin{abstract}
Briefly tracing the history of hydrologic modeling, this paper discusses the progress that has been achieved in hydrologic modeling since the advent of computer and what the future may have in store for hydrologic modeling. Hydrologic progress can be described through the developments in data collection and processing, concepts and theories, integration with allied sciences, computational and analysis tools, and models and model results. It is argued that with the aid of new information gathering and computational tools, hydrology will witness greater integration with both technical and non-technical areas and increasing applications of information technology tools. Furthermore, hydrology will play an increasingly important role in meeting grand challenges of the twenty-first century, such as food security, water security, energy security, health security, ecosystem security, and sustainable development.
\end{abstract}

Keywords: Hydrologic models, Data processing, Computational tools, Hydrologic advances, Future outlook

\section{Introduction}

Hydrology has a long history dating back to several millennia (Biswas 1970). However, the birth of hydrologic modeling can be traced to the 1850 s when Mulvany (1850) developed a method for computing the time of concentration and hence the rational method for computing peak discharge which is still used for urban drainage design, Darcy (1856) who conducted experiments on flow-through sands and developed what is now referred to as Darcy's law which laid the foundation of quantitative groundwater hydrology, and Fick's first law which states that under steady-state conditions the diffusive flux is proportional to the concentration gradient (spatial) which laid the foundation of water quality hydrology. About half a century earlier, Dalton (1802) formulated the law of evaporation which states that the rate of evaporation is directly proportional to the difference between saturation vapor pressure at the water surface and the actual vapor pressure in the air. This law constituted the foundation for developing the physics of evaporation. For a period of over a century until the

\footnotetext{
${ }^{*}$ Correspondence: vsingh@tamu.edu

Department of Biological and Agricultural Engineering \& Zachry

Department of Civil Engineering, Texas A\&M University, 321 Scoates Hall,

2117 TAMU, College Station, TX 77843-2117, USA
}

1960s, many groundbreaking advances in modeling different components of the hydrologic cycle were made. Some of these advances were based on the laws of mathematical physics and some had their basis in laboratory and/or field experiments. The current state of hydrologic science and engineering owes a great deal to the pre-1960 advances. The handbook of applied hydrology edited by Chow (1964) provided an up-to-date account of hydrologic advances until the 1960s, whereas the handbook of hydrology edited by Maidment (1993) and the encyclopedia of hydrology and water resources edited by Hershey and Fairbridge (1998) dealt with advances that occurred during the intervening period. Singh and Woolhiser (2002) provided a historical account of developments that occurred in modeling different components of the hydrologic cycle.

The decade of the 1960s witnessed the birth of computer revolution and hydrologic modeling took a giant leap forward. The computer provided the power for doing computations that was not available before. As a result, a new branch of hydrology, called digital or numerical hydrology, was born. Another branch that came into being was statistical or stochastic hydrology that often required analyses of large volumes of data. Then, several major advances ensued. First, simulation of the entire hydrologic cycle became a reality, as 
illustrated by the development of the Stanford Watershed Model (Crawford and Linsley 1966) which was followed in the decades to come by umpteen watershed models that were developed all over the world (Singh 1995; Singh and Frevert 2002a, b, 2006). Second, optimization or operations research techniques were developed, which formed the basis for reservoir management and operation as well as river basin simulation. Some of these techniques were also used for calibrating hydrologic models (Beven 2001; Duan et al. 2003). Third, two- and three-dimensional modeling was made possible because of advances in numerical mathematics. Consequently, two- and three-dimensional models of groundwater as well as of infiltration and soil water flow were developed (Bear 1979; Pinder and Celia 2006; Remson et al. 1971). Fourth, simultaneous simulation of water flow and sediment and pollutant transport was undertaken; likewise, simultaneous simulation of different phases of flow, such as liquid and gaseous, was done (Bear and Verruijt 1987; Charbeneau 2000). Fifth, modeling at large spatial scales, such as a large river basin like the Mississippi, and that at small temporal scales, such as seconds or minutes, was undertaken (Molley and Wesse 2009; Sorooshian et al. 2008). Sixth, integration of hydrology with allied sciences became possible. For example, it was possible to couple hydrology with climatology for precipitation modeling and forecasting (Sorooshian et al. 2008), with geomorphology for river basin geometric representation (Baker et al. 1988; Bates and Lane 2002; Beven and Kirkby 1993), with hydraulics for describing flow characteristics (Singh 1996), with soil physics for quantifying soil texture and structure (Bohne 2005; Guymon 1994; Miyazaki 2006; Smith et al. 2002; Singh 1997), and with geology for aquifer characterization (Delleur 1999; Fetter 1980; Singh 2017a, b, c). The coupling of hydrology with ecosystems gave rise to ecohydrology (Eagleson 2002; Gordon et al. 2006; Rodriguez-Iturbe and Porporato 2004). Climate change and global warming became part of hydrologic analysis (Arnell 1997). A more detailed account of developments in different components of the hydrologic cycle is given in Singh (2013, 2014, 2015, 2017a).

In the decades that followed, computing prowess increased exponentially and hydrology began maturing and expanding in both depth (vertically) and breadth (horizontally). Tools from fluid mechanics, statistics, information theory, and mathematics were employed and became part of hydrology (Bras and Rodriguez-Iturbe 1985; Clarke 1998; Gelhar 1993; Mays and Tung 1992; Singh et al. 2007; Tung and Yen 2005). Further, computer also made possible the development of user-friendly software, and tools for date acquisition, storage, retrieval, processing, and dissemination (Croley 1980; Hoggan 1989). Remote sensing tools, such as radar and satellites, came into being that made possible to acquire spatial data for large areas (Engman and Gurney 1991; Hogg et al. 2017; Lakshmi 2017; Lakshmi et al. 2015). Likewise, geographical information systems (GIS) were developed for processing huge quantities of raster and vector data (Maidment 2002). The past two decades witnessed the development of artificial neural networks, fuzzy logic, genetic programming, and wavelet models (Kumar et al. 2006; Ross 2010; Sen 2010; Tayfur 2012). New theories borrowed from other areas were introduced in hydrology. Examples of these theories are entropy theory (Singh 2013, 2014, 2015, 2016, 2017b), copula theory (Singh and Zhang 2018), chaos theory (Sivakumar 2017), network theory (Sivakumar et al. 2017), and catastrophe theory (Poston and Stewart 1978; Zeeman 1978). These theories will find increasing place in hydrologic modeling in the years ahead.

Another area that mushroomed subsequent to the precomputer era is instrumentation. New instruments which were more accurate and sophisticated were developed for measuring all kinds of hydrologic variables, such as velocity, soil moisture, water and air quality parameters, fluxes in porous media, energy fluxes, and so on. Further, instrumentation for data transmission from place of measurement to place of storage, processing, storage, retrieval, and dissemination became highly robust and accessible (Liang et al. 2013; Sivakumar and Berndtsson 2010).

The objective of this paper, therefore, is to provide a snapshot of major advances that have occurred for over a century and a half, discuss where hydrology is headed as a science and engineering, and conclude with a personal reflection on future outlook.

\section{History of hydrologic developments}

There have been a large number of developments in hydrology since the 1850s, so it will be difficult to do justice to describe all of them. Therefore, only a snapshot of some of the major developments from a personal perspective will be provided. For convenience of easy reference, these developments will be organized topic-wise rather than chronologically.

\section{Watershed geomorphology}

In 1945 Horton, derived a set of empirical laws that are now called Horton laws which laid the foundation of quantitative geomorphology. These laws were the law of channel numbers, law of channel lengths, and law of stream slopes. He developed a scheme for channel and basin ordering, called Horton ordering. Horton (1932) also defined drainage density and length of overland flow. He investigated landform development and streamflow generation dominated by overland flow. Strahler 
(1952) modified Horton's method for ordering channel networks which is now referred to as Horton-Strahler ordering scheme. Schumm (1956) developed the law of stream areas. Because discharge is highly correlated with drainage area, as shown by Hack (1957) for mean annual discharge and Leopold and Miller (1956), and Gray and Wigham (1970), a law of discharge can be formulated as shown by Singh (1992). Strahler (1957) formulated the law of drainage basin similarity, but Gray (1961) showed that not all basins possessed geometric similarity. Gray (1961) established the relation between drainage area and length which was also investigated by Smart and Surkan (1967). Shreve (1966) developed a statistical law of channel numbers. Using the theory of minimum energy dissipation rate, Yang (1971) developed the law of average stream fall. Much of the progress made in subsequent years draws heavily from these foundational contributions. Fitzpatrick (2017) has reported on watershed geomorphologic characteristics. Smith (1974) derived hydraulic geometry of steady state channels from conservation principles and sediment transport laws. Using entropy theory and theory of minimum energy dissipation rate, Singh et al. (2003a, b) derived a hierarchy of downstream hydraulic geometry and Singh and Zhang (2008a, b) upstream hydraulic geometry. Applications of channel network are included in Beven and Kirkby (1993) and flood geomorphology is presented in Baker et al. (1988). Rodriguez-Iturbe and Rinaldo (2001) have described river basins using fractal geometry. The watershed geomorphology has played a fundamental role in developing runoff prediction models for ungauged basins (Bloschl et al. 2013; Wagner et al. 2004).

\section{Hydraulic geometry}

Hydraulic geometry is of two types, at-a-station and downstream, and encompasses relations of channel width, depth, velocity, roughness, and slope each with discharge (Wolman 1955). Leopold and Maddock (1953) derived these hydraulic geometry relations which are of power form. Because of their great practical value in design of stable channels, river flow control works, river improvement works, and irrigation schemes, there is a large body of literature describing the derivation of these relations using different types of theories, including regime theory (Blench 1952), tractive force theory (Lane 1955), minimum entropy production theory (Leopold and Langbein 1962), stability theory (Stebbings 1963), minimum variance theory (Langbein 1964), minimum channel mobility theory (Dou 1964), minimum energy degradation theory (Brebner and Wilson 1967), threshold geometry theory (Li 1974), hydrodynamic theory (1974), minimum stream power theory (Chang 1980), maximum sediment discharge and Froude number theory (Ramette
1980), maximum sediment discharge theory (White et al. 1982), maximum friction theory (Davies and Sutherland 1983), minimum unit stream power theory (Yang and Song 1986), thermodynamic theory (Yalin and da Silva 1997, 1999), minimum energy dissipation theory (Rodriguez-Iturbe et al. 1992), principle of least action (Huang and Nanson 2000), and entropy theory (Deng and Zhang 1964; Singh et al. 2003a, b; Singh and Zhang 2008a, b). Each theory leads to unique hydraulic geometry relations, meaning different values of exponents. Singh (2003) has discussed characteristics of these relations with regard to their basis, tendency to equilibrium state, limitations of the equilibrium assumption, validity of power relations, stability of exponents in power relations, effect of channel patterns, effect of stream size, dependence of exponents on climatic and environmental factors and land use, extension to drainage basins, and impact of boundary conditions.

\section{Surface runoff}

In 1850, Mulvany developed a method, called rational method, for computing peak discharge due to a rainfall event with uniform intensity and duration equal to or greater than the time of concentration. The method was meant for small urban watersheds which are in use for urban drainage design to date. St. Venant de (1871) derived equations for modeling surface flow and these equations are now called St. Venant equations. Two decades later, Manning (1895) developed an equation for computing flow velocity in open channels. Imbeau (1892) developed a relation between storm runoff peak and rainfall intensity. Sherman (1932) developed the unit hydrograph concept which laid the foundation of linear systems hydrology. Horton (1939) derived a semi-empirical formula for overland flow. Barnes (1940) developed a technique for hydrograph separation. Applying hydraulic principles, Keulegan (1944) showed the adequacy of simplified momentum equation for modeling overland flow. Izzard (1944) conducted experiments on overland flow on paved surfaces. Clark (1945) developed a unit hydrograph method for deriving the rainfall-runoff hydrograph. These contributions laid the foundation for conceptual as well as physically based rainfall-runoff modeling. However, for application of these methods the amount of surface runoff was assumed to be known and, therefore, rainfall excess was known.

In 1956, the Soil Conservation Service (SCS) [now called National Resources Conservation Service (NRCS)] of the U.S. Department of Agriculture (USDA) developed a method, now called SCS-Curve Number $(\mathrm{CN})$ method, based on a large amount of data, for computing the amount of runoff generated by a rainfall event, taking into account abstractions, antecedent soil moisture 
condition, hydrologic condition of land use and land cover, and soil type through curve number. This method is still quite popular for determining the amount of runoff or rainfall excess from small and medium agricultural watersheds, and has been extended to urban and forested watersheds. Nielsen et al. (1959) investigated the sourcearea contribution to runoff.

In 1956, the U.S. Army Corps of Engineers published the summary report of the snow investigations as a book entitled "Snow Hydrology" that laid the foundation for much of the work that has since ensued. The book described virtually all aspects of the snow environment. Martinec (1960) developed a degree-day method for determining snowmelt. Anderson (1968) developed and tested snowpack energy balance equations. Colbeck (1972) developed a theory of water percolation in snow and Colbeck (1975) developed a theory of water movement through a layered snowpack. Gray and Prowse (1993) provided an excellent discussion of different aspects of snow and floating ice. Singh et al. (1997a, b) developed the kinematic wave theory of vertical movement of snowmelt water through snowpack and of saturated basal flow in a snowpack. Kuchment (2017) proved an excellent review of snowmelt runoff generation and modeling. Singh et al. (2011) prepared an encyclopedia of snow, ice and glaciers.

Nash (1957) developed a theory of instantaneous unit hydrograph (IUH) that led to what is now called the Nash model. Nash (1959) also developed the theory of moments for determining his model parameters. Dooge (1959) developed the generalized unit hydrograph theory that included the Nash IUH theory as a special case. These IUH theories led to the development of systems hydrology detailed by Singh $(1988,1989)$ in which systems techniques can be applied to flow routing, base flow, water quality routing, erosion and sediment transport. Combining laws of geomorphology with the IUH theory Rodriguez-Iturbe and Valdes (1979) developed the geomorphologic unit hydrograph that has since received a great deal of attention and is now frequently used in practice.

Physically based surface runoff modeling was based on the St. Venant equations and simplifications thereof whose solutions required the use of numerical algorithms and became popular in the 1960s and the ensuing decades. Depending on the simplification, these equations give rise to five types of waves: dynamic waves, steady dynamic waves, gravity waves, diffusive waves, and kinematic waves, and hence five types of models. Using different techniques, Lighthill and Whitham (1955), Iwagaki (1955), Woolhiser and Liggett (1967), Ponce and Simons (1977), Menendez and Norscini (1982), and Ferrick (1985) analyzed the characteristics of these waves. They showed that diffusive and kinematic wave approximations would suffice for most cases. Singh (2017a, b, c) presented the kinematic wave theory of surface runoff. Woolhiser and Liggett (1967) derived the kinematic wave number which served as a criterion for the kinematic wave approximation. This work gave the real impetus to the popularity of kinematic wave approximation. Morris and Woolhiser (1980) revised the kinematic wave number with the use of Froude number. Singh (1994) derived the error differential equation for judging the accuracy of kinematic and diffusive approximations. Moramarco et al. (2008a, b) made a comprehensive analysis of the accuracy of kinematic wave and diffusion wave approximations. Kibler and Woolhiser (1972) developed the kinematic cascade. Smith and Woolhiser (1971) explicitly incorporated infiltration in overland flow modeling. Berod et al. (1999) developed a geomorphologic kinematic wave model. These investigations established that the kinematic wave approximation would be sufficiently accurate for surface runoff modeling and has since been a standard technique. Singh (1996) prepared two treatises on kinematic wave modeling in surface water hydrology and environmental hydrology that comprehensively summarize the kinematic wave literature.

\section{Reservoir and channel flow routing}

Analogous to surface runoff modeling, both hydrologic systems and physically based techniques have been applied to route flows through reservoirs and channels. Puls (1928) presented a method for reservoir flow routing. MeCarthy and others (U.S. Army Corps of Engineers 1936) developed the Muskingum method for routing of flow in channels. Kalinin and Miljukov (1957) developed a unit hydrograph model for channel flow routing. Cunge (1969) developed a method for estimating the Muskingum method parameters from hydraulic and channel geometry characteristics. Since then, the Muskingum method has been a popular method and its several variants have been developed. Koussis (2009) provided an assessment and a review of the hydraulics of storage flood routing 70 years after the introduction of the Muskingum method.

Stoker $(1953)$ and Isaacson et al. $(1954,1956)$ used the complete St. Venant equations for flood routing in the Ohio River. Abbott (1976) and Grupert (1976) summarized the flood routing models. Fread (1984) developed a one-dimensional dynamic wave model in a single or branched waterway. Linear forms of the St. Venant equations were employed since the work of Dooge (1967), and Dooge and Harley (1967). Kundzewicz (1986) discussed physically based flow routing methods. Abbott (1979) presented numerical methods for solving free surface flow equations. 
Hayami (1951) employed diffusion wave approximation for flood routing. Lighthill and Whitham (1955) showed that diffusion waves were described by a convection-diffusion equation. Cunge (1969) showed the connection between Muskingum method and convection-diffusion equation. Huang (1978) used a finite difference solution of kinematic wave equation for routing flows in channels. Singh (1996) has given a full account of different routing methods. Perumal and Price (2017) have reviewed reservoir and channel routing.

\section{Interception and depression storage}

Interception loss in humid forested watersheds may account for as much as $25 \%$ of annual precipitation. Helvey and Patrick (1965) found that this loss might be of the order of $15 \mathrm{~cm}$ for such watersheds. Horton (1919) developed a series of empirical equations for computing storm interception for a variety of vegetative covers. Linsley et al. (1949) developed an exponential type model for computing interception by vegetation. Merriam (1960) modified the Horton model. Bultot et al. (1972) derived empirical relationships for computing interception loss. Deguchi et al. (2006) computed the influence of seasonal changes in canopy structure on infiltration loss. Gash (1979) developed an analytical model for infiltration loss by forests. Gerrits et al. (2010) discussed the spatial and temporal variability of canopy and forest floor interception in a beech forest.

Horton (1939) and Holtan (1945) empirically evaluated depression storage. Turner (1967) derived curves for depression storage intensity as a function of time for different antecedent conditions. Using a digital surface model, Ullah and Dickinson (1979a, b) investigated geometric properties of depressions for hydrologic modeling. Soil Conservation Service (1956) included interception and depression storage losses as a fraction of maximum soil moisture retention capacity in the SCS-CN model (Mishra and Singh 2010c). Linsley et al. (1949) presented an exponential model for computing surface depression storage for a given effective rainfall. Borselli and Torri (2010) discussed the relationship between surface storage and soil roughness and slope on impervious areas and suggested an empirical model.

\section{Evaporation}

Evaporation and evapotranspiration are amongst the most important components of the hydrologic cycle and their significance increases with the increase in timescale. Richardson (1931) and Cummings (1935) investigated evaporation from lakes. Thornthwaite (1948) developed an empirical model for computing monthly evaporation which is still used. Combining energy balance and mass transfer, Penman (1948) developed what is now referred to as the combination method for computing evaporation from saturated water bodies as well as vegetated surfaces. The Penman method laid the foundation for subsequent developments in the evaporation field. Budyko (1955, 1974) prepared an atlas of heat balance of Earth. Monteith $(1965,1973,1981)$ modified the Penman method which is now called the Penman-Monteith method. Morton $(1965,1969)$ developed a method, called complementary method, for computing regional evaporation. Priestley and Taylor (1972) developed an equation for computing evaporation. Doorenbos and Pruitt (1977) developed methods for computing evapotranspiration and hence crop water requirements. Jensen and Allen (2016) have comprehensively summarized methods for computing evaporation, evapotranspiration, and irrigation water requirements. Hobbins and Huntington (2017) have provided an up-to-date account of evapotranspiration and evaporative demand.

\section{Infiltration and soil water flow}

Infiltration is fundamental for computing surface runoff modeling, groundwater recharge, and agricultural irrigation. In 1911, using physical principles Green and Ampt developed a formula for computing infiltration capacity rate which is one of the most commonly used infiltration formulae today. Richards (1931) derived what is now called Richards equation for modeling flow-through unsaturated soils (Richards 1931, 1965). This equation laid the foundation for vadose zone hydrology. Kostiakov (1932) derived an empirical equation for computing infiltration capacity rate. Horton $(1933,1939)$ developed a theory of infiltration which was based on a hydrologic systems concept. Horton (1940) tested his infiltration theory on experimental plots. Philip (1957) developed a theory of infiltration that led to Philip infiltration equation. Mein and Larson (1973) developed a model for computing infiltration under steady rain. Fok (1987) summarized developments in infiltration and its application. Singh and Yu (1990) developed a generalized framework for infiltration and derived several popular infiltration models as special cases. Smith et al. (2002) prepared a treatise on infiltration theory for hydrologic applications. Corradini et al. (2017) have reviewed the state of art of infiltration modeling.

\section{Subsurface flow}

Subsurface flow is also referred to interflow and is sometimes divided into quick interflow and delayed interflow (Chow 1964) and generates subsurface runoff. Lowdermilk (1934), Hursh and Brater (1944), Hursh (1936) observed subsurface flow as part runoff hydrograph in humid regions. Hoover and Hursh (1943), and Hursh (1944) showed that subsurface storm flow constituted a 
significant portion of streamflow in humid areas. Remson et al. (1960) and Hewlett (1961a, b) developed concepts of source area and partial area that contributed to streamflow generation and showed that downslope unsaturated flow could contribute to streamside saturation and hence generate streamflow.

Macropores and preferential flow paths can significantly contribute to subsurface flow under certain conditions. Germann $(1985,2014)$ reviewed preferential flow and has given a full account based on the kinematic wave theory. Macropores are pipe structures in soil matrix and result from physical processes, such as erosion due to desiccation cracking and biological activity such as animal burrows and decaying plant root channels. Tanaka et al. (1988) found that more than $90 \%$ of runoff originated from below the ground mainly through pipe flow. Leaney et al. (1993) noted that winter stormflow reached the channel primarily through macropores. Newman et al. (1998) inferred that most of the lateral subsurface flow occurred in B horizon through macropores. Thus, subsurface flow-through macropores and other preferential flow paths can be a major contributor to streamflow generation.

\section{Groundwater}

In 1852, Darcy conducted experiments on flow-through sands and developed what is now referred to as Darcy's law which laid the foundation of quantitative groundwater hydrology. Theis (1935) derived the relation between drawdown in piezometric head and pump discharge from a well. Muskat (1937) published a treatise on flow of homogeneous fluids in porous media. Hubbert (1940) described the theory of groundwater motion. Meinzer (1942) edited a book on hydrology. Jacob $(1943,1944)$ established the relationship between infiltration and groundwater. Dynamic changes in streamside groundwater flow were reported by Roessel (1950). Hantush and Jacob (1955) derived equations for unsteady radial flow in leaky aquifers. Hantush $(1960,1964)$ revised the theory of leaky aquifers. Freeze (1975) presented a stochastic conceptual analysis of one-dimensional groundwater flow in nonuniform homogeneous media. The field of groundwater has since expanded dramatically. A large number of books have been published that detail hydrogeological, scientific, numerical, and engineering aspects of groundwater. Freeze and Cherry (1979) discussed groundwater and contamination from a hydrogeology perspective (Fair and Hatch 1933), Bear (1979) hydraulics of groundwater, Todd (1980) hydrology of groundwater, Domenico and Schwartz (1990) physical and chemical hydrogeology of groundwater, Gelhar (1993) stochastic aspects, and Delleur (1999) groundwater engineering. Pham and Tsai (2017) have reviewed groundwater modeling.

\section{Erosion and sediment yield}

Cook (1936) identified major factors that impact erosion by water. Considering the effect of slope steepness and slope length, Zingg (1940) developed an empirical equation for calculating field soil loss. Smith (1941) developed an equation considering additional factors, such as cropping system and support practices. Browning et al. (1947) included soil erodibility and management factor in the Smith equation. Smith and Whitt (1948) developed an equation as product of average annual soil loss for claypan soils for a specific rotation, slope length, slope steepness, and row direction; slope steepness; slope length; soil erodibility; and support practice. Musgrave (1947) developed an equation considering factors reflecting the effect of rainfall and surface runoff as impacted by slope steepness and length, and vegetative cover. Using 10,000 plot years of basic runoff and soil loss data, Wischmeier and Smith (1957, 1965, 1978) developed the Universal Soil Loss Equation (USLE) that has undergone several revisions and its new incarnation is Revised USLE (Renard et al. 1997). A comprehensive account of soil erosion prediction and prediction is treated in Soil Conservation Society of America (1977).

Soil erosion by water was also investigated using hydraulic equations. Foster and Meyer (1972) derived an equation for sediment transport under steady-state condition for rill and inter-rill detachment and/or deposition. Hjelmfelt et al. (1975) considered the kinematic wave formulation of erosion on a plane. Singh and Regl (1983a, b) developed the kinematic wave theory for erosion due to rainfall. Considering surface flow and rain-drop impact, Hairsine and Rose (1992a, b) derived a model for soil erosion which was based on the equation developed by Rose et al. (1983a, b). Both USLE and physically based equations of soil erosion have been included in a wide range of watershed hydrology or erosion models which have recently been reviewed by Pandey et al. (2016). Flanagan and Huang (2017) have provided a review of soil erosion.

\section{Sediment transport}

There is vast literature on sediment transport in reservoirs, rivers and channels that has culminated into a new field of sedimentation engineering. A number of formulae have been developed for bed load and suspended load. The earliest bed load formula was developed by DuBoys (1879) assuming uniform grains moving as series of layers. Shields (1936) developed a criterion for incipient motion of sediment particles. Assuming graded sediment, Meyer-Peter and Muller (1948) developed a formula for bed load sediment transport. With extensive analysis based on fluid mechanics and probability theory, Einstein $(1942,1950)$ developed a bed load function for sediment transport in open channels. Brown (1950) 
modified the Einstein formula. Parker et al. (1982) developed a bed load equation for coarse-bed material and gravel-bed rivers.

Einstein (1950) computed suspended sediment discharge considering vertical variations in velocity and sediment concentration. Colby (1964) determined bedmaterial discharge as a function of mean flow velocity, depth, mean sediment size, water temperature and concentration of fine sediment. Using physical laws, Bagnold (1966) developed an approach for transport of sediment. Engelund and Hansen (1967) derived a sediment transport equation using the concept of stream power. Yang (1972) developed a bed-material load equation based on the rate of energy dissipation of flow. Ackers and White (1973) developed an equation to sediment transport in open channel flow as a function of mobility factor. The state of art of sedimentation engineering was provided by Vanoni (1975). Simons and Senturk (1977) discussed sediment transport technology. An up-to-date account of sedimentation engineering, including processes, measurements, modeling, and practice, was presented by Garcia (2008). Papanicolaou and Abban (2017) have provided an up-to-date account of channel erosion and sediment transport, whereas Sarkar (2017) has discussed sedimentation in floodplains, lakes and reservoirs.

\section{Pollutant transport}

Water quality has always been a major concern but in hydrology it started receiving attention since the 1970s with the establishment of Environmental Protection Agency (EPA). Tremendous work has since been done in the hydrology of surface water, vadose zone, and groundwater quality. Both physical and biochemical aspects of water quality have been emphasized. Water quality has been investigated using both systems approach as well as science-based approach. In 1925 Streeter and Phelps derived a model for dissolved oxygen in surface waters. Taylor $(1953,1954)$ developed a theory of dispersion of matter in flow in pipes. Elder (1959) determined dispersion in turbulent open channels. Fisher $(1967,1968)$ described mixing in inland and coastal streams. Yotsukura and Sayre (1976) developed a model for transverse mixing in natural channels. Yotsukura (1977) derived equations for solute transport in turbulent natural flow. Thomann (1972) provided a treatise on systems approach to water quality management. Rinaldi et al. (1979) prepared a treatise on river water quality modeling and control. Tchobanoglous and Schroeder (1985) comprehensively discussed water quality characteristics, modeling and modification. Thomann and Mueller (1987) presented principles of surface water quality modeling and control. Ji (2008) treated the hydrodynamic modeling of water quality of rivers, lakes, and estuaries.
De Josselin de Jong (1958) developed a random walk model for describing longitudinal and transverse dispersion in granular materials. (Scheidegger 1961) described the general theory of dispersion in porous media. Bear and Verruijt (1987) presented the theory and applications of transport in porous media. Palmer (1992) and Fetter (1999) discussed principles of contaminant hydrogeology (Fick 1855). Charbeneau (2000) discussed the hydraulics of groundwater and pollutant transport. Gelhar (1993) presented stochastic method in subsurface hydrology.

Agricultural chemicals, fertilizers, weedicides, and pesticides are applied to agricultural fields for increasing crop productivity. Many chemical compounds generated by industries are sometimes dumped on the soil surface. Sometimes there is a chemical spill on the surface. Whatever the source or cause, some of the pollutants enter the soil, contaminant it, and percolate down to contaminate the ground water. Earliest attempts to model solute transport in the unsaturated zone were made by soil scientists. Nielsen and Biggar (1961) discussed a wide range of problems related to miscible displacement and pollutant transport. Knisel (1980) reported a field-scale model for chemicals, runoff, erosion from agricultural management systems, called CREAMS. Leonard et al. (1987) presented a model, called GLEAMS: groundwater loading effects of agricultural systems. Carlsel et al. (1985) developed a pesticide root zone model (PRZM). Shaffer and Larson (1987) reported a soil-crop simulation model for nitrogen, tillage, and crop-residue management, called NTRM. Smith (1990) described an integrated simulation model for transport of nonpoint source pollutant at field scale, called OPUS. In the 1980s, the U.S. Department of Agriculture-Agricultural Research Service reviewed the state of water quality modeling and started to develop a model that would address a wide range of agricultural management practices. The resulting model was Root-Zone Water Quality Model (RZWQM) (RZWQM Team 1992) which is a physical, chemical, and biological process model and has since undergone a number of revisions. This model is more advanced than any of the other models developed before. Zamani and Bombardelli (2014) presented analytical solutions for transport of non-reactive species in unsaturated soil. Zamani and Ginn (2017) reviewed the state of art of pollutant transport in vadose zone as well as numerical models, including SUTRA (Voss and Provost 2002), VS2DT (Healy 1990), HYDRUS (Radcliffe and Simunek 2010), among others.

\section{Reservoir operation}

For reservoir design, operation, and management, water surplus, deficit, range, and storage are computed. Two different tracks, deterministic and stochastic, were 
pursued for reservoir operation and management. The deterministic track entailed various optimization techniques. Indeed these techniques gave birth to the field of water resource systems engineering. One of the earliest studies in this field was by Mass et al. (1962) under the Harvard water Program. Hall and Dracup (1970) authored a popular book on water resources systems engineering. With the advent of computers and their growing computational power, this field took a giant leap in the 1970s and 1980s. As a result, numerous popular books and other publications enriched the literature. A sample of books includes those by Haimes (1977), Loucks et al. (1981), and Meta Systems, Inc. (1975). Lund et al. (2017) have provided reservoir operation design. The optimization techniques employed for analysis and synthesis of water resources systems allowed to integrate seemingly disparate areas, such as economics, politics, decision-making, environmental science, and ecology with hydrology, hydraulics, and water resources engineering. Thus, it was possible to undertake planning of water resources at the river basin scale.

The stochastic track assumed that water surplus, deficit, range, and storage needed for reservoir design, operation and management varies randomly. Therefore, the probability theory was applied to analyze them and compute their probabilities. Three methods have been used for design of reservoirs: empirical, experimental or data generation, and analytical. The best example of an empirical method is the mass curve or Rippl diagram applied in England in 1883. The data generation method is also referred to as Monte Carlo method, synthetic hydrology, or operational hydrology method. Range analysis is an example of the analytical method. Yevjevich (1972) discussed range analysis. Hurst (1951) investigated longterm storage capacities of reservoirs which led to what is now known as Hurst coefficient. Thomas and Fiering (1962) presented a mathematical synthesis of streamflow sequences for analysis of river basins. Matalas (1967) reported a mathematical assessment of synthetic hydrology. Mandelbrot and Wallis (1969) performed computer experiments with fractional Gaussian noises. Valencia and Schaake (1972) presented disaggregation processes in hydrology.

The probability theory of reservoir storage or storage theory was developed in the 1950s, although Saverenskiy (1940) computed probabilities of high and low flows through a probability routing method. Moran (1954) initiated the storage theory considering serially independent reservoir inflows with a fixed probability distribution. Moran's theory is based on Markov process. Gould (1961) incorporated failures within a year. Lloyd (1963) developed a probabilistic storage theory considering serially dependent flows. Kottegoda (1980) discussed stochastic methods for water resources systems, including reservoirs.

\section{Flood frequency analysis}

Hazen (1930) presented a treatise on frequency analysis of both maximum and minimum flood flows. Foster (1934) derived duration curves. Kendall (1938) derived a measure of rank correlation. Weibull (1939) presented a formula for plotting probability against its quantile. Gumbel (1941) derived a distribution, now called Gumbel distribution, for frequency analysis of annual maximum flows. This distribution is the extreme value type one distribution (Boughton 1980). Langbein (1949) analyzed flood frequencies using partial duration series. Chow (1951) presented a general formula for frequency analysis based on frequency factor. Jenkinson (1955) derived a general extreme value distribution for frequency analysis of meteorological data. Gringorten (1963) presented a formula for plotting positions.

Hershfield (1962) prepared rainfall frequency atlas of the United States for durations from 30 min to $24 \mathrm{~h}$ and return periods from 1 to 100 years, published as U.S. Weather Bureau Technical Report 40, Washington, D.C. NERC (1975) presented a treatise of flood studies. Houghton (1978) presented the Wakeby distribution for modeling flood flows. Todorovic (1978) developed a methodology for frequency analysis using random number of random variables. Landwehr et al. $(1979,1980)$ developed the probability weighted moments for distribution parameter estimation. Cunnane $(1978,1989)$ provided a review of frequency distributions and presented a less biased plotting position formula. Hosking (1990) developed the L-moments method for estimating frequency distribution parameters. Dalrymple (1960) developed a flood index method for regional flood frequency analysis. Kite (1988) presented different methods of flood frequencies and risk analysis. Rao and Hamed (2000) provided a comprehensive discussion of flood frequency distributions. Stedinger (2017) has presented an up-todate account of flood frequency distributions and Ouarda (2017) of regional flood frequency modeling. Vogel and Castellarin (2017) have discussed risk, reliability, and return periods for hydrologic design.

\section{Drought analysis}

Recent years have witnessed much interest in drought modeling, partly because of the uncertainty about water availability and supply triggered by climate change. Many areas in the world are experiencing drought or a drought-like situation or downright scarcity. Drought has been defined in different ways. The World Meteorological Organization (WMO 1986) defined drought as a sustained, extended deficiency in precipitation. The 
Food and Agriculture Organization (FAO 1983) of the United Nations defined drought hazard as 'the percentage of years when crops fail from lack of moisture. Gumbel (1963) defined drought as the smallest annual value of daily streamflow, whereas Palmer (1965) described drought as a significant deviation from the normal hydrologic conditions of an area. Linsley et al. (1959) defined drought as a sustained period of time without significant rainfall. Clearly, the drought definition varies with the variable used to define it. Mishra and Singh (2010a) provided a comprehensive discussion of drought concepts.

Drought modeling encompasses characterization, space-time analysis, forecasting, and climate change impact. The variables associated with drought are precipitation for hydrometeorological drought, streamflow or lake level for hydrologic drought, groundwater level for groundwater drought, and soil moisture for agricultural drought. The main drought characteristics are intensity, duration, severity, and spatial extent. Several indices have been defined, based on combinations of precipitation, temperature, soil moisture, and evapotranspiration, to characterize, assess, and forecast droughts. Commonly used indices are: Palmer severity drought index (PDSI) (Palmer 1965), Crop Moisture Index (CMI) (McKee et al. 1993), Soil Moisture Drought Index (SMDI) (Hollinger et al. 1993), and Vegetation Index (VI) (Liu and Kogan, 1996). Also, climatic indices, such as El Nino Southern Oscillation (ENSO), Southern Oscillation Index (SOI), Sea Surface Temperature (SST), North Atlantic Oscillation (NAO), Pacific Decadal Oscillation (PDO), Inter-decadal Pacific Oscillation (IPO), and Atlantic Multi-decadal Oscillation (AMO), are used for long-lead drought forecasting. Mishra and Singh (2010b) provided a review of drought models that include regression models, time series models, probability models, artificial neural network models, and hybrid models; and spatio-temporal drought analysis; drought modeling under climate change scenarios. Mishra et al. (2015) edited a special issue of Journal of Hydrology on drought processes, modeling, and mitigation. Hao et al. (2018) reviewed seasonal drought prediction, advances, challenges, and future prospects.

\section{Watershed models}

It is seen that for a period of over a century until the 1960s prior to the computer era, many groundbreaking advances in modeling different components of the hydrologic cycle were made. Some of these advances were based on the laws of mathematical physics and some had their basis in laboratory and/or field experiments. The current state of hydrologic science and engineering owes a great deal to the pre-1960 advances. With the advent of computer, the digital revolution started in the decade of the 1960s and by the 1970s computers became accessible to universities, government agencies and industry. The resulting computing capability made possible the simulation of the entire hydrologic cycle and the birth of numerical hydrology. In 1966, Crawford and Linsley reported the first watershed model, called Stanford Watershed Model (SWM) that became HSPF (Hydrologic Simulation Package-Fortran) in its latter incarnation and BASINS (Better Assessment Science Integrating Point and Nonpoint Sources) in its current life. In subsequent years, a number of models were developed in the U.S. Examples of popular ones are HEC-1 (Hydrologic Engineering Center 1968) which in current form is HECHMS (Hydrologic Modeling Simulation), SWMM (Storm Water Management Model) (Metcalf and Eddy et al. 1971), NWS-RFS (National Weather Service-River Forecast System) (Burnash et al. 1973), SSARR (Streamflow Synthesis and Reservoir Regulation) System (Rockwood 1982), and USGS Rainfall-Runoff Model (Dawdy et al. 1970) which later became PRMS (Precipitation Runoff Modeling System) (Leavesley et al. 1983). A large number of other hydrology simulation models were developed in Australia, Canada, England, Sweden, and other countries. Many of these models are described in Singh (1995), and Singh and Frevert (2002a, b, 2006). Singh and Woolhiser (2002) appraised the state of art of mathematical modeling of watershed hydrology. Borah (2011) reviewed and compared hydrologic procedures of storm-event watershed models. Donigian et al. (2017) have provided a comprehensive discussion of continuous watershed models, and Gupta and Sorooshian (2017) have discussed the calibration and evaluation of watershed models.

\section{Data observation and tools}

Empirical observations form the basis of much of what we know about hydrologic systems as well as for their operation and management. For hydrologic modeling, the types of data needed are hydrometeorologic, physiographic, geomorphologic, pedologic, geologic, hydrometric, land/land cover, and agricultural. Local, state, and federal agencies have been collecting data that are relevant for their operational and management purposes, but the data so collected have also been and continue to be used for research and generating new knowledge. The technology for data collection has undergone a revolutionary change over the past three decades in four ways. First, data collection tools are much more accurate, such as velocity measurements by acoustic Doppler velocimetry (ADV). Second, it is now possible to collect data that was not possible before, such as direct measurement of discharge. Third, it is possible to collect spatial data rather than point data, such as spatial representation of rainfall field by radar. Fourth, it is now possible 
to collect data in remote inaccessible areas using satellite technology.

Remote sensing tools, particularly satellites and radar, are becoming more popular these days (Engman and Gurney 1991). Since the launch of Landsat-1 [also known as the Earth Resources Technology Satellite (ERTS)], developed by NASA (National Aeronautics and Space Administration) and operated by USGS (United States Geological Survey), in 1972, six other satellites have been launched and land surface data have since been collected (Shen et al. 2013). The next generation of satellites, called Landsat Data Continuity Mission (LDMC), was launched in 2013. Most NASA satellite land measurements can be found in the NASA Land Measurement Portal (http:// landportal.gsfc.nasa.gov) which includes data products in four categories: surface radiation budget, vegetation parameters, land cover/land use changes, and land hydrosphere. More specifically, one can obtain for hydrologic modeling synoptic data of meteorological inputs; soil and land use parameters; inventories of water bodies, lakes, reservoirs, rivers, etc.; snow cover and ice fields; and water quality parameters. Other agencies in Japan, China, and India have also launched spaceborne sensors/ missions for studying the terrestrial water cycle components. Examples include Advanced Microwave Scanning Radiometer (AMSR) and Soil Moisture and Ocean Salinity (SMOS) for estimating soil moisture; Tropical Rainfall Measuring Mission (TRMM) for precipitation; Moderate Resolution Imaging Spectroradiometer (MODIS) for vegetation; JASON-1 and JASON-2 and TOPEX-POSEIFON for surface water level; and Gravity Recovery and Climate Experiment (GRACE) for groundwater and evaporation. Lakshmi et al. (2015) presented a treatise on remote sensing of the terrestrial water cycle. Lakshmi (2017) edited a book on remote sensing of hydrological extremes.

Weather radar is being employed for spatial mapping of rainfall field and daily weather forecasting. Both groundbased and spaceborne radars are used. With the use of bias correction techniques, radar rainfall data are usually scaled to match data being observed at rainfall gauging stations. Even though radar rainfall data in many cases are available on web, their use with quality control/assurance and bias correction is recommended. Pathak et al. (2017) edited a special issue of Journal of Hydrologic Engineering on radar rainfall and operational hydrology that contains papers dealing with radar rainfall data estimation, improvement, and validation; application of radar rainfall data; and use of radar rainfall for flood forecasting.

\section{Geographical information systems}

Geographical information systems (GIS) are a technology for stacking, analyzing, and retrieving large amounts of data (Singh and Fiorentino 1996). The term geographical information here means the $x$-, $y$ - and $z$-coordinates of land surfaces defined in a coordinate system. Because GIS is a data processing tool, tools that provide or record information, such as digital elevation model (DEM), topographic surveys, land use and land cover maps, can be dealt within the GIS environment (Maidment 2002). These days, global positioning systems (GPS) and GIS can be combined to provide more complete information. The use of GIS permits integration of spatial, non-spatial, and ancillary data into hydrologic models and thus significantly strengthens hydrologic modeling capability (Mujumdar and Nagesh Kumar, 2012). Griffin et al. (2017) have comprehensively discussed GIS and their applications.

\section{Tools and methods for analysis}

The past half a century has witnessed an unprecedented development of new tools and techniques for analysis of hydrologic data. Many of these tools were developed outside of hydrology but they were appropriately tailored for hydrologic applications. Some of these tools include artificial neural networks (Tayfur and Singh 2017), fuzzy logic (Bogardi 2017), genetic algorithms (Kawamura and Merabtene 2017), relevance vector machines (Tripathi and Govindaraju 2017), wavelets (Labat 2017), outlier analysis (Panu and Ng 2017), time series analyses (Sveinsson and Salas 2017), nonstationarity detection and analysis (2017), geostatistical methods (Dwivedi et al. 2017), generalized frequency distributions (Singh and Zhang 2017), data assimilation methods (Todini and Biondi 2017), calibration and validation methods (Todini and Biondi 2017), Bayesian methods (Kuczera et al. 2017), optimization methods (Dozier et al. 2017), nonparametric methods (Lall and Rajagopalan 2017), uncertainty assessment and decision-making (Todini 2017), risk and reliability analysis (Tung and Mays 2017), scaling and fractals (Veneziano and Lepore 2017), chaos theory (Sivakumar 2017), copula theory (Genest and Chebana 2017), entropy theory (Singh 2013, 2014, 2015, 2016, 2017a, c), data mechanistic modeling (Young 2017), decomposition methods (Serrano 2017), and network theory (Sivakumar et al. 2017). These techniques have greatly contributed to not only the increased understanding of hydrologic systems but also hydrologic practice.

\section{Emerging areas}

Many new areas have merged during the past couple of decades and others will emerge in the decades ahead. Hydrology of global warming and climate change is an area that has been receiving a lot of attention in public fora, primarily because of increased frequency of hydrometeorologic extremes and significant variability in the 
space-time distribution of precipitation (McCuen 2017). Ecosystem hydrology is another area that has recently emerged. Hydrologic impacts of hydraulic fracturing are in much public debate these days. Transport of biochemical and microorganisms is receiving plenty of traction. Hydrology of hurricanes and typhoons is a newly emerging area. Atmospheric rivers are receiving much attention. Hydrology of long-distance water transfer is receiving global attention these days. Hydrology has a value to society and a new area, called social hydrology, has lately emerged and is getting traction in scientific discourses.

\section{Integration of concepts and processes}

Because of computing prowess and sophisticated instrumentation available these days, integration in and across hydrology is occurring rapidly. Hydrology and climatology are being integrated and hydroclimatology is emerging with renewed emphasis. Ecology and hydrology have combined to give birth to ecohydrology. Likewise, coastal science and hydrology are being integrated leading to coastal hydrology. The field of hydrology is broadening and the areas, such as social science, culture and religion, politics, economics, and health sciences are being interfaced with hydrologic sciences. Greater integration of concepts from intelligent systems, software engineering, information engineering, and humanities is envisioned in the years ahead.

\section{Future outlook}

With advances in data capturing and analysis capabilities and information technologies, it seems that the future of hydrology will be even brighter. It can be expected that new tools will be at the disposal of hydrology. For example, drones will become commonplace for acquiring spatial data. Hydrologic models will become so user-friendly that little hydrologic knowledge will be needed to operate them, just like one does not need to be an automobile engineer to drive a car or an electrical engineer to operate an electrical system. Each model, however, simple or complicated, will be associated with a statement of uncertainty. New frontiers of hydrology will unfold with the use of cell phones and newly emerging information technologies. Hydrologic forecasting capability will multiply. There will be greater interaction between the user and the model and the modeler. This has already started happening through what is now regarded as social hydrology. Hydrology will play an increasing role in meeting grand challenges of this century, such as water security, food security, energy security, environmental security, health security, food-water-energy nexus, and sustainable development. These grand challenges will also compel educators to revisit the delivery of hydrologic education and tailor it to produce leaders of tomorrow who will be well equipped to address the societal needs of tomorrow. Likewise, research funding agencies will have to rethink and reprioritize their direction of funding in concert with these grand challenges and pressing societal needs.

Social or rural hydrology, extraterrestrial water, water and food and energy security are newly emerging areas. For management of hydrologic systems, political, economic, legal, social, cultural, and management aspects will need to be integrated. It is vital that both hydrologic science and engineering applications are equally emphasized. Hydrologic science must not be allowed to be overtaken by data cranking methods borrowed from outside. At the same time, data analysis tools must be seamlessly integrated with hydrologic science.

\section{Conclusions}

The following conclusions are drawn from this study:

1. Hydrologic modeling has come a long way from its modest beginning in the 1850s. Advances in modeling have occurred at an increasing pace, primarily driven by easy access to almost limitless computing capability, sophisticated instrumentation, and remote sensing and GIS capabilities.

2. Integration of hydrology with allied areas is occurring increasingly and will so continue.

3. The role of hydrology is coming into sharper focus, because of global warming and climate change on one hand and water, food and energy security on the other hand.

4. Information technology is being assimilated in hydrology without much resistance.

5. Hydrology is receptive in adopting techniques being developed in mathematics, statistics, and sciences.

Authors' contributions

VPS conceptualized the framework and crafted the manuscript. The author read and approved the final manuscript.

\section{Acknowledgements \\ The author greatly appreciates the invitation extended by Professor B. Siva- kumar, University of New South Wales, Australia, to prepare this paper and is grateful for the support extended from time to time. \\ Competing interests \\ The author declares that he has no competing interests.}

Availability of data and materials

Not applicable.

Consent for publication

The author consents for publication.

Ethics approval and consent to participate Not applicable. 


\section{Funding}

No funding source is available.

\section{Publisher's Note}

Springer Nature remains neutral with regard to jurisdictional claims in published maps and institutional affiliations.

Received: 7 September 2017 Accepted: 4 May 2018

Published online: 28 May 2018

\section{References}

Abbott MB (1976) Discussion of "Review of models of tidal waves," by J.B. Hinwood and I.G. Walls. J Hydraul Div 102(HY8):1145-1148

Abbott MB (1979) Computational hydraulics: elements of the theory of free surface flows. Pitman, London, p 324

Ackers P, White WR (1973) Sediment transport: new approach and analysis. J Hydraul Eng ASCE 99(11):2041-2069

Anderson EA (1968) Development and testing if snowpack energy balance equations. Water Resour Res 4(1):19-37

Arnell N (1997) Global warming, river flows and water resources. John Wiley, Chichester, p 224

Bagnold RA (1966) An approach to the sediment transport problem from general physics. U.S. Geological Survey Professional Paper 422-I

Baker VR, Kochel RC, Patton PC (eds) (1988) Flood geomorphology. John Wiley \& Sons, New York, p 503

Barnes BS (1940) Discussion on analysis of runoff characteristics by O. H. Meyer. Trans Am Soc Civ Eng 105:104-106

Bates PD, Lane SN (eds) (2002) High resolution flow modelling in hydrology and geomorphology. John Wiley, Chichester, p 374

Bear J (1979) Hydraulics of groundwater. McGraw-Hill Book Publishing Company, New York, p 567

Bear J, Verruijt A (1987) Modeling groundwater flow and pollution. D. Reidel Publishing Company, Dordrecht, p 414

Berod DD, Singh VP, Musy A (1999) A geomorphologic kinematic-wave (GKW) model for estimation of floods from small alpine watersheds. Hydrol Process 13:1391-1416

Beven KJ (2001) Rainfall-runoff modeling: the primer. John Wiley, Chichester, p 360

Beven KJ, Kirkby MJ (eds) (1993) Channel network hydrology. John Wiley, Chichester, p 319

Biswas AK (1970) History of Hydrology. North Holland Publishing Company, Amsterdam, p 336

Blench T (1952) Regime theory for self-formed sediment bearing channels. Trans Am Soc Civil Eng 117:383-408

Bloschl G, Sivapalan M, Wagener T, Viglione A, Savenije H (eds) (2013) Runoff prediction in ungaged basins: synthesis across processes, places and scales. Cambridge University Press, Cambridge

Bogardi I (2017) Fuzzy logic. Chapter 12. In: Singh VP (ed) Handbook of applied hydrology. McGraw-Hill Education, New York, pp 12-1-12-5

Bohne K (2005) An introduction into applied soil hydrology. CATENA VERLAG GMBH, Reiskirchen, p 231

Borah DK (2011) Hydrologic procedures of storm event watershed models: a comparison review and comparison. Hydrol Process 25(22):3472-3489

Borselli L, Torri D (2010) Soil roughness, slope and surface storage relationship for impervious areas. J Hydrol 393:389-400

Boughton WC (1980) A frequency distribution for annual floods. Water Resour Res 16(2):347-354

Bras RG, Rodriguez-lturbe I (1985) Random functions and hydrology. Addison Wesley, Reading, p 559

Brebner A, Wilson KC (1967) Derivation of the regime equations from relationships for pressurized flow by use of the principle of energy-degradation rate. Proc Inst Civil Eng 36:47-62

Brown CB (1950) Sediment transportation. In: Rouse H (ed) Engineering hydraulics. John Wiley \& Sons, New York

Browning GM, Parish CL, Glass JA (1947) A method for determining the use and limitation of rotation and conservation practices in control of soil erosion in lowa. Soil Sci Soc Am Proc 23:249-264
Budyko MI (1955) On the determination of evaporation from the land surface. Meteorol Gidrol 1:52-58 (Russian)

Budyko MI (1974) Climate and life. Int Geophys Ser 18:508

Bultot FG, Dupriez DL, Bodeaux A (1972) Interception of rain by forest vegetation: estimation of daily interception by using mathematical models. J Hydrol 17(3):193-223

Burnash RJC, Ferral RL, McGuire RA (1973) A generalized streamflow simulation system-conceptual modeling for digital computers. Report, U.S. National Weather Service, Silver Spring, Maryland, and Department of Water Resources, State of California, Sacramento, California

Carlsel RF, Mulkey LA, Lorber MN, Baskin LB (1985) The pesticide root zone model (PRZM): a procedure for evaluating pesticide leaching threats to groundwater. Ecol Model 30:49-69

Chang HH (1980) Geometry of gravel stream. J Hydraul Div ASCE 106(HY9):1443-1456

Charbeneau RJ (2000) Groundwater hydraulics and pollutant transport. Prentice Hall, Upper Saddle River, p 593

Chow VT (1951) A general formula for hydrologic frequency analysis. Trans Am Geophys Union 32(2):231-237

Chow VT (ed) (1964) Handbook of applied hydrology. McGraw-Hill Book Publishing Company, New York

Clark CO (1945) Storage and the unit hydrograph. Trans Am Soc Civ Eng 110:1419-1488

Clarke RT (1998) Stochastic processes for water scientists: developments and applications. John Wiley, New York, p p183

Colbeck SC (1972) A theory of water percolation in snow. J Glaciol 11(63):369-385

Colbeck SC (1975) A theory of water movement through a layered snowpack. Water Resour Res 11(2):261-266

Colby BR (1964) Discharge of sands and mean-velocity in sand-bed streams. In: U.S. Geological Survey Professional paper 462-A. Washington, D.C.

Cook HL (1936) The nature and controlling variables of the water erosion process. Soil Sci Soc Am Proc 1:60-64

Corradini C, Morbidelli R, Govindaraju RS (2017) Infiltration modeling Chapter 45. In: Singh VP (ed) Handbook of applied hydrology. McGraw-Hill Education, New York, pp 45-1-45-9

Crawford NC, Linsley RK (1966) Digital simulation in hydrology: stanford watershed simulation-IV. Technical Report 39, Stanford University, Palo Alto

Croley TE (1980) Synthetic-hydrograph computations on small programmable calculators. lowa institute of Hydraulic Research, University of lowa, lowa City, p 236

Cummings NW (1935) Evaporation from water surfaces: status of present knowledge and need for further investigations. Trans Am Geophys Union 16(2):507-510

Cunge J (1969) On the subject of flood propagation computation method (Muskingum method). J Hydraul Res 7(2):205-230

Cunnane C (1978) Unbiased plotting positions-A review. J Hydrol $37(3 / 4): 205-222$

Cunnane C (1989) Statistical distributions for flood frequency analysis. Operational hydrology Report No. 33, World Meteorological Organization, WMO-No. 718, Geneva, Switzerland

Dalrymple T (1960) Flood frequency analysis. U.S. Geological Survey Water Supply Paper 1543-A, Washington, D.C

Dalton J (1798-1802) Experimental essays on the constitution of mixed gases; on the force of steam or vapor from water and other liquids in different temperatures, both in a torricellian vacuum and in air; on evaporation; and on the expansion of gases by heat. Manchester Literature and Philosophical Society Memoirs and Proceedings, vol 5, pp 535-602

Darcy H (1856) Les fontaines publiques de la ville de Dijon. Victor Dalmont, Paris

Davies TRH, Sutherland AJ (1983) Extremal hypotheses for river behavior. Water Resour Res 19(1):141-148

Dawdy DR, Litchy RW, Bergmann JM (1970) Rainfall-runoff simulation model for estimation of flood peaks for small drainage basins. Geological Survey Open File Report, Washington, D.C

Deguchi A, Hattori S, Park H-T (2006) The influence of seasonal changes in canopy structure on interception loss: application of the revised Gash model. J Hydrol 418:80-102

Delleur JW (1999) The handbook of groundwater engineering. CRC Press, Boca Raton 
Deng Z, Zhang K (1964) Morphologic equations based on the principle of maximum entropy. Int J Sed Res 9(1):31-46

Domenico PA, Schwartz PW (1990) Physical and chemical hydrogeology. John Wiley, New York

Donigian AS, Crawford NH, Imhoff JC (2017) Continuous watershed modeling Chapter 60. In: Singh VP (ed) Handbook of applied hydrology. McGrawHill, New York, pp 60-1-60-11

Dooge JCl (1959) A general theory of the unit hydrograph. J Geophys Res 64(2):241-256

Dooge JCI (1967) Linear theory of open channel flow. Report, Department of Civil Engineering, University College, Cork, Ireland

Dooge JCl, Harley BM (1967) Linear routing in uniform open channels. In: Proceedings, international hydrology symposium, vol 1. Fort Collins, Colorado, pp 57-63

Doorenbos AGM, Pruitt WO (1977) Crop water requirements. Irrigation and drainage paper 24, Food and Agriculture Organization, United Nations, Rome, Italy

Dou GR (1964) Hydraulic geometry of plain alluvial rivers and tidal river mouth. J Hydraul Eng 2:1-13 (in Chinese)

Dozier A, Arabai M, Labadi J, Fontane D (2017) Optimization approaches for integrated water resources management. Chapter 24. In: Singh VP (ed) Handbook of applied hydrology. McGraw-Hill Education, New York, pp 24-1-24-7

Duan Q, Gupta HV, Sorooshian S, Rousseau AN, Turcotte R (eds) (2003) Calibration of watershed models. AGU, Washington, p 345

DuBoys P (1879) Le Rhone et les rivieres as lit affouillable. Annales des Ponts et Chausees 18(5):141-195

Dwivedi D, Dafflon B, Arora B, Wainwright HM, Finsterle S (2017) Spatial analysis and geostatistical methods. Chapter 20. In: Singh VP (ed) Handbook of applied hydrology. McGraw-Hill Education, New York, pp 20-1-20-9

Eagleson PS (2002) Ecohydrology: darwinian expression of vegetation form and function. Cambridge University Press, Cambridge, p 443

Einstein HA (1942) Formulas for the transportation of the bed load. Trans ASCE 107:561-573

Einstein HA (1950) The bed load function for sediment transportation in open channel flows. U.S. Department of Agriculture Soil Conservation Service Technical Bulletin 1026

Elder JW (1959) The dispersion of marked fluid in a turbulent shear flow. J Fluid Mech 5(4):544-560

Engelund F, Hansen E (1967) A monograph on sediment transport in alluvial rivers. Teknisk Vorlag, Copenhagen

Engman ET, Gurney RJ (1991) Remote sensing in hydrology. Chapman and Hall, New York

Fair GM, Hatch LP (1933) Fundamental factors governing the streamline flow of water through sand. J Am Water Works Assoc 25:1551-1565

Ferrick MG (1985) Analysis of river waves. Water Resour Res 21(2):209-220

Fetter CW (1980) Applied hydrogeology. Merrill Publishing Company, Columbus, p 592

Fetter CW (1999) Contaminant hydrogeology. Prentice Hall, Upper Saddle River, p 500

Fick A (1855) Ueber diffusion. Ann Der Physik 94:59-86. https://doi. org/10.1002/andp.18551700105 (in German)

Fisher HB (1967) The mechanisms of dispersion in natural streams. J Hydraul Div ASCE 93(HY6): 187-216

Fisher JB (1968) Dispersion prediction in natural streams. J Sanit Eng ASCE 94(SA5):927-943

Fitzpatrick FA (2017) Watershed geomorphological characteristics. Chapter 44. In: Singh VP (ed) Handbook of applied hydrology. McGraw-Hill, New York, pp 44-1-44-12

Flanagan DC, Huang CH (2017) Soil erosion. Chapter 64. Handbook of applied hydrology. McGraw-Hill, New York, pp 64-1-64-6

Fok YS (1987) Infiltration development and application. In: Proceedings of the international conference on infiltration development and application. University of Manoa, Honolulu, p 582

Food and Agriculture Organization (1983) Guidelines: land evaluation for rainfed agriculture. FAO Soils Bulletin 52, Rome, Italy

Foster HA (1934) Duration curves. Trans Am Soc Civ Eng 99:1213-1267

Foster GR, Meyer LD (1972) A closed-form soil erosion equation for upland areas sedimentation symposium in Honor Professor HA Einstein. Shen HW (Ed). Colorado State, University, Fort Collins, Colorado, pp $12.1-12.19$
Fread DL (1984) Flood routing. Chapter 14. In: Anderson MG, Burt TP (eds) Hydrological forecasting. Wiley, New York

Freeze RA (1975) A stochastic-conceptual analysis of one-dimensional groundwater flow in nonuniform homogeneous media. Water Resour Res 11(5):725-741

Freeze RA, Cherry JA (1979) Groundwater. Prentice Hall, Englewood Cliffs

Garcia MH (ed) (2008) Sedimentation engineering: processes, measurements, modeling, and nature. ASCE Manuals and reports on engineering practice no. 110, ASCE, Reston, Virginia, p 1132

Gash JHC (1979) An analytical model of rainfall interception by forests. Quart J R Meteorol Soc 105:43-55

Gelhar LW (1993) Stochastic subsurface hydrology. Prentice Hall, Englewood Cliffs, p 390

Genest C, Chebana F (2017) Copula modeling in hydrologic frequency analysis. Chapter 30. In: Singh VP (ed) Handbook of applied hydrology. McGraw-Hill Education, New York, pp 30-1-30-10

Germann P (1985) Kinematic wave approach to infiltration and drainage into soil and from soil macrospores. Trans ASAE 28(3):745-749

Germann P (2014) Preferential flow: stokes approach to infiltration and drainage. Institute of Geography, Bern

Gerrits AMJ, Pfister I, Savenji HHG (2010) Spatial and temporal variability of canopy and forest floor interception in a beech forest. Hydrol Process 24:3011-3025

Gordon ND, Mcmahon TA, Finlayson BL, Gippel CJ, Nathan RJ (2006) Stream hydrology: an introduction for ecologists. John Wiley, Chichester, p 429

Gould BW (1961) Statistical methods for estimating the design capacity of dams. J Inst Eng Aust 33:405-416

Gray DM (1961) Interrelationships of watershed characteristics. J Geophys Res 66(4):1215-1223

Gray DM, Prowse TD (1993) Snow and floating ice Chapter 7. In: Maidment DR (ed) Handbook of hydrology. McGraw-Hill Book Company, New York, pp 7.1-7.58

Gray DM, Wigham JM (1970) Peak flow-rainfall events. In: Gray DM (ed) Handbook on the principles of hydrology. National Research Council of Canada, Ottawa

Green WH, Ampt CA (1911) Studies on soil physics: 1. Flow of water and air through soils. J Agric Sci 4:1-24

Griffin RE, Cruise JF, Ellenburg WL, Al-Hamdan M, Handyside C (2017) Geographical information systems. In: Singh VP (ed) Handbook of applied hydrology, Chap 9, pp 9-1-9-6

Gringorten II (1963) A plotting rule for extreme probability paper. J Geophys Res 88(3):813-814

Grupert JP (1976) Numerical computation of two-dimensional flows. J Waterways Harbors Coast Eng Div ASCE 104(WW1):1-12

Gumbel EJ (1941) The return period of flood flows. Ann Math Stat 12(2):163-190

Gumbel EJ (1963) Statistical forecast of droughts. Bull Int Assoc Sci Hydrol 8(1):5-23

Gupta HV, Sorooshian S (2017) Calibration and evaluation of watershed models. Chapter 61. In: Singh VP (ed) Handbook of applied hydrology. McGraw-Hill, New York, pp 61-1-61-11

Guymon GL (1994) Unsaturated zone hydrology. Prentice Hall, Englewood Cliffs, p 210

Hack JT (1957) Studies of longitudinal stream profiles in Virginia and Maryland. U.S. Geological Survey Professional Paper 294-B, Washington, D.C

Haimes YY (1977) Hierarchical analyses of water resources systems: modeling and optimization of large-scale systems. McGraw-Hill, New York, p 478

Hairsine PB, Rose CW (1992a) Modeling water erosion due to overland flow using physical principles: 1, sheet flow. Water Resour Res 28(1):237-243

Hairsine PB, Rose CW (1992b) Modeling water erosion due to overland flow using physical principles: 2, Rill flow. Water Resour Res 28(1):245-250

Hall WA, Dracup JA (1970) Water resources systems engineering. McGraw-Hill, New York, p 372

Hantush MS (1960) Modification of the theory of leaky aquifers. J Geophys Res 65:3713-3725

Hantush MS (1964) Hydraulics of wells. Adv Hydrosci 1:281-432

Hantush MS, Jacob CE (1955) Nonsteady radial flow in an infinite leaky aquifer. Trans Am Geophys Union 36:95-100

Hao Z, Singh VP, Xia Y (2018) Seasonal drought prediction advances, challenges, and future prospects. Rev Geophys 56:34. https://doi. org/10.1002/2016RG000549 
Hayami S (1951) On the propagation of flood waves. Bulletin 1. Disaster Prevention Research Institute, Kyoto University, Kyoto

Hazen A (1930) Flood flows: a study of frequencies and magnitudes. Wiley, New York

Healy EW (1990) Simulation of solute transport in variably saturated porous media with supplemental information on modifications to the U.S. Geological Survey's Computer Program VS2D, U.S. Geological Survey Water Resources Investigations Report 90-4025, Denver, Colorado, p 125

Helvey JD, Patrick JH (1965) Design criteria for interception studies. In: Proceedings of the WMO/IASH symposium on design of hydrometeorological networks, Quebec City, Quebec, Canada

Hershey RW, Fairbridge RW (eds) (1998) Encyclopedia of hydrology and water resources. Kluwer Academic Publishers, Dordrecht, p 803

Hershfield DM (1962) Rainfall frequency atlas of the United States for durations from 30 minutes to 24 hours and return periods from 1 to 100 years. Washington, D.C., Weather Bureau Technical Report

Hewlett JD (1961a) Soil moisture as a source of base flow from steep mountain watersheds. USDA Forest Service, Southeast Forest Experiment Station Paper 132, Georgia

Hewlett JD (1961 b) Some ideas about storm runoff and base flow. U. S. D. A. Forest Service, Southeast Forest Experiment Station, Annual Report, pp 62-66

Hjelmfelt AT, Piest RP, Saxton KE. (1975) Mathematical modeling of erosion on upland areas. In: Proceedings of the congress of the 16th international association for hydraulic research, Sao Paulo, Brazil, 2, p 40-47

Hobbins MT, Huntington J (2017) Evapotranspiration and evaporative demand. Chapter 42. In: Singh (ed) Handbook of applied hydrology, McGraw-Hill, New York, pp 42-1-41-18

Hogg Y, Zhang Y, Khan SI (eds) (2017) Hydrologic remote sensing: capacity building for sustainability and resilience. CRC Press, Boca Raton, p 395

Hoggan DH (1989) Computer-assisted floodplain hydrology and hydraulics. McGraw-Hill, New York, p 518

Hollinger SE, Isard SA, Welford MR (1993) A new soil moisture drought index for predicting crop yields. In: Preprint, eighth conference on applied climatology, Anaheim, CA, Amer. Meteor. Soc., pp 187-190

Holtan HN (1945) Time condensation in hydrograph analysis. Trans Am Geophys Union 26:407-413

Hoover MD, Hursh CR (1943) Influence of topography and soil-depth on runoff from forest land. Trans Am Geophys Union 24:693-697

Horton RE (1919) Rainfall interception. Mon Weather Rev 147:603-623

Horton RE (1932) Drainage basin characteristics. Trans Am Geophys Union 13:350-361

Horton RE (1933) The role of infiltration in the hydrologic cycle. Trans Am Geophys Union 145:446-460

Horton RE (1939) Analysis of runoff plot experiments with varying infiltration capacities. Trans Am Geophys Union 20(IV):683-694

Horton RE (1940) An approach toward a physical interpretation of infiltration capacity. Soil Sci Soc Am Proc 5:399-417

Horton RE (1945) Erosional development of streams and their drainage basins: hydrophysical approach to quantitative geomorphology. Bull Geol Soc Am 56:275-370

Hosking JRM (1990) L-moments: analysis and estimation of distributions using linear combinations of order statistics. J R Stat Soc Ser B 52(2):105-124

Houghton JC (1978) Birth of a parent: the Wakeby distribution for modeling flood flows. Water Resour Res 14(6):1 105-1369

Huang YH (1978) Channel routing by finite difference method. J Hydraul Div ASCE 104(HY10):1379-1393

Huang HW, Nanson GC (2000) Hydraulic geometry and maximum flow efficiency as products of the principle of least action. Earth Surf Landforms 25:1-16

Hubbert MK (1940) Theory of groundwater motion. J Geol 48:784-944

Hursh CR (1936) Storm water and absorption. Trans Am Geophys Union 17(II):301-302

Hursh CR (1944) Appendix B-report of the subcommittee on subsurface flow. Trans Am Geophys Union 25:743-746

Hursh CR, Brater EF (1944) Separating hydrographs into surface- and subsurface-flow. Trans Am Geophys Union 25:863-867

Hurst HE (1951) Long-term storage capacities of reservoirs. Trans Am Soc Civ Eng 116:776-808
Hydrologic Engineering Center (1968) HEC-1 flood hydrograph package: User's manual. Army Corps of Engineers, Davis

Imbeau ME (1892) La Durance: regime, crues et inundations. Annales des Ponts et Chaussees, Memoires et Documents, 7 series, III (I), 5-18 (in

\section{French)}

Isaacson E, Stoker JJ, Troesch A (1954) Numerical solution of flood prediction and river regulation problems. Report II, IMM-NYU-235, Institute of mathematical Sciences, New York University, New York

Isaacson E, Stoker JJ, Troesch A (1956) Numerical solution of flood problems in rivers. J Hydraul Div ASCE 84(HY5):1-18

Iwagaki Y (1955) Fundamental studies on the runoff analysis by characteristics. Bulletin 10. Disaster Prevention Research Institute, Kyoto University, Kyoto

Izzard CF (1944) The surface profile of overland flow. Transac Am Geophys Union 25(Pt. VI):959-968

Jacob CE (1943) Correlation of groundwater levels and precipitation on Long Island, New York: 1. Theory. Trans Am Geophys Union 24:564-573

Jacob CE (1944) Correlation of groundwater levels and precipitation on Long Island, New York: 2.Correlation of data. Trans Am Geophys Union 24:321-386

Jenkinson AF (1955) The frequency distribution of annual maximum (or minimum) values of meteorological elements. Quart J R Meteorol Soc 81:58-171

Jensen ME, Allen RG (2016) Evaporation, evapotranspiration, and irrigation requirements. ASCE manuals and Report on engineering practice no. 70, ASCE Press, Reston, p 744

Ji ZG (2008) Hydrodynamics and Water Quality: Modeling Rivers, Lakes, and Estuaries. Hoboken, Wiley Interscience, p 676

Josselin De, de Jong G (1958) Longitudinal and transverse diffusion in granular deposits. Trans Am Geophys Union 39:67-74

Kalinin GP, Miljukov PI (1957) On the computation of unsteady flow in open channels Meteorologiya i Gidrologiya Zhuzurnal, vol 10. U.S.S.R, Leningrad

Kawamura A, Merabtene T (2017) Evolutionary computing: Genetic algorithms. Chapter 13. In: Singh VP (ed) Handbook of applied hydrology. McGraw-Hill Education, New York, pp 13-1-13-4

Kendall MG (1938) A new measure of rank correlation. Biometrika 30:81-93

Keulegan GH (1944) Spatially variable discharge over a sloping plane. Trans Am Geophys Union 25(IV):959-965

Kibler DF, Woolhiser DA (1972) Mathematical properties of the kinematic cascade. J Hydrol 15:131-147

Kite GW (1988) Frequency and risk analysis in hydrology. Water Resources Publications in Hydrology, Littleton

Knisel WG (ed) (1980) CREAMS: a field scale model for chemicals, runoff, and erosion from agricultural systems. USDA-SEA Conservation Research Report 26. U.S. Department of Agriculture, Washington, D. C, p 643

Kostiakov AM (1932) On the dynamics of the coefficient of water percolation in soils and of the necessity of studying it from a dynamic point of view for purposes of amelioration. In:Transactions, sixth communications, international soil science society, Russian, Part 1, pp 17-29

Kottegoda NT (1980) Stochastic water resources technology. John Wiley, New York, p 384

Koussis AD (2009) Assessment and review of the hydraulics of storage flood routing 70 years after the presentation of the Muskingum method. Hydrol Sci J 54(1):43-61

Kuchment L (2017) Snowmelt runoff generation and modeling. Chapter 50. In: Singh VP (ed) Handbook of applied hydrology. McGraw-Hill Education, New York, pp 50-1-51-9

Kuczera G, Kavetski D, Renard B, Thyer M (2017) Bayesian methods. Chapter 23. In: Singh VP (ed) Handbook of applied hydrology. McGraw-Hill Education, New York, pp 23-1-23-10

Kumar P, Alameda JC, Bajcsy P, Folk M, Markus M (2006) Hydroinformatics: data integrative approaches in computation, analysis, and modeling. Taylor \& Francis, Boca Raton, p 534

Kundzewicz ZW (1986) Physically based hydrological flood routing methods. Hydrol Sci J 31(2):237-261

Labat D (2017) Harmonic analysis and wavelets Chapter 15. In: Singh VP (ed) Handbook of applied hydrology. McGraw-Hill Education, New York, pp 15-1-15-8

Lakshmi V (ed) (2017) Remote sensing of hydrological extremes. Berlin, Springer, p 250 
Lakshmi V, Alsdorf D, Anderson M, Nianmaria S, Cosh M, Entin J, Huffman GJ, Kustas W, van Oevelen P, Painter TH, Parajka J, Rodell M, Rudiger C (eds) (2015) Remote sensing of the terrestrial water cycle. geophysica monograph 206. American Geophysical Union and John Wiley \& Sons, Hoboken, p 556

Lall U, Rajagopalan B (2017) Nonparametric methods. Chapter 25. In: Singh VP (ed) Handbook of applied hydrology. McGraw-Hill Education, New York, pp 25-1-25-8

Landwehr JM, Matalas NC, Wallis JR (1979) Probability weighted moments compared with some traditional techniques in estimating Gumbel parameter and quantiles. Water Resour Res 15(5):1055-1064

Landwehr JM, Matalas NC, Wallis JR (1980) Quantile estimation with more or less floodlike distributions. Water Resour Res 16(3):547-555

Lane EW (1955) Design of stable channels. Trans ASCE 120:1234-1260

Langbein WB (1949) Annual floods and the partial duration series. Trans Am Geophys Union 28:879-881

Langbein WB (1964) Geometry of river channels. J Hydrau Div ASCE 90(HY2):301-311

Leaney FW, Smettem KRJ, Chittleborough DJ (1993) Estimating the contribution of preferential flow to subsurface runoff from a hillslope using deuterium and chloride. J Hydrol 147:83-103

Leavesley GH, Lichty RW, Troutman BM, Saindon LG (1983) Precipitationrunoff modeling system-user's manual. U. S. Geological Survey Water Resources Investigations Report 83-4238. Denver, Colorado

Leonard RA, Knisel WG, Still DA (1987) GLEAMS: groundwater loading effects of agricultural management systems. Trans ASAE 30:1403-1418

Leopold LB, Langbein WB (1962) The concept of entropy in landscape evolution. Geol. Survey Prof. Paper 500-A, U. S. Gov. Printing Off., Washington, D. C

Leopold LB, MaddockTJ (1953) Hydraulic geometry of stream channels and some physiographic implications. U.S. Geologic Survey Professional Papers 252. Washington, D. C, p 55

Leopold LB, Miller JP (1956) Ephemeral streams-hydraulic factors and their relation to the drainage net. U.S. Geological Survey Professional Paper 282A, Washington, D.C

Li RM (1974) Mathematical modeling of response from small watershed, Unpub. Ph. D. dissert.Colo. St. Univ., Fort Collins, Colorado, p 212

Liang S, Li X, Xie X (eds) (2013) Land surface observation, modeling and data assimilation. World Scientific, Singapore, p 466

Lighthill MJ, Whitham GB (1955) On kinematic waves: 1. Flood movement in long rivers. Proc R Soc London Series A 229:281-316

Linsley RK, Kohler MA, Paulhus JLH (1949) Hydrology for engineers. McGrawHill, New York, p 508

Linsley RK, Kohler MA, Paulhus JLH (1959) Applied hydrology. McGraw-Hill Book Publishing Company, New York

Liu WT, Kogan FN (1996) Monitoring regional drought using the vegetation condition index. Int J Remote Sens 17:2761-2782

Lloyd EH (1963) A probability theory of reservoirs with serially correlated inputs. J Hydrol 1:99-128

Loucks DP, Stedinger JR, Haith DA (1981) Water resources systems planning and analysis. Prentice Hall, Englewood Cliffs, p 559

Lowdermilk WC (1934) Forests and streamflow: a discussion of Hoyt-Trozell report. J Forest 21:296-307

Lund JR, Hui R, Escriva-Bou A, Porse EC, Adams L, Connaughton J, Kasuri L, Lord B, Siegfried L, Thayer R, Sandoval-Solis S, Yi S (2017) Reservoir operation design. Chapter 130. In: Singh VP (ed) Handbook of applied hydrology. McGraw-Hill, New York, pp 130-131

Maidment DR (ed) (1993) Handbook of hydrology. McGraw-Hill, New York

Maidment DR (ed) (2002) Arc hydro. ESRI Press, Redlands, p 208

Mandelbrot BB, Wallis JR (1969) Computer experiments with fractional Gaussian noises: part 1. Averages and variances. Water Resour Res 5(1):228-241

Manning R (1895) On the flow of water in open channels and pipes. Trans Inst Civil Eng 20:161-207 (supplement vol 24, pp 179-207)

Martinec J (1960) The degree day factor for snowmelt runoff forecasting. In: International union of geodesy and geophysics, general assembly of Helsinki. International association of hydrologic sciences, communication on surface waters, IAHS Publication 51, pp 468-477

Mass AM, Hufschmidt M, Dorman R, Thomas HA, Marglin S, Fair G (1962) Design of water resources systems. Harvard University Press, Cambridge
Matalas NC (1967) Mathematical assessment of synthetic hydrology. Water Resour Res 3(4):937-945

Mays LW, Tung YK (1992) Hydrosystems engineering and management. McGraw-Hill, New York, p 530

McCuen RH (2017) Statistical detection of nonstationarity: issues and needs. Chapter 19. In: Singh VP (ed) Handbook of applied hydrology. McGrawHill Education, New York, pp 19-1-19-6

McKee TB, Doesken NJ, Kleist J (1993) The relationship of drought frequency and duration to time scales. In: Paper presented at 8th conference on applied climatology, Am. Meteorol. Soc., Anaheim, Calif

Mein RG, Larson CL (1973) Modeling infiltration during a steady rain. Water Resour Res 9:384-394

Meinzer O (ed) (1942) Hydrology. Dover, New Yok

Menendez AN, Norscini R (1982) Spectrum of shallow waves: an analysis. J Hydraul Div 108(HY1):75-93

Merriam RA (1960) A note on the interception loss equation. J Geophys Res 65(11):3850-3851

Meta Systems Inc (1975) Systems analysis in water resources planning. Water Information Center Inc, Port Washington, New York, p 393

Metcalf and Eddy, Inc., University of Florida and Water Resources Engineers, Inc (1971) Storm water management model, vol 1-final report. EPA Report No. 11024DOV07/71 (NITS PB-203289), Environmental Protection Agency, Washington, D.C

Meyer-Peter E, Muller R (1948) Formula for bed load transport. In: Proceedings, 2nd meeting, international association for hydraulic research (IAHR), vol 6

Mishra AK, Singh VP (2010a) A review of droughts. J Hydrol 391:202-216

Mishra AK, Singh VP (2010b) Drought modeling-a review. J Hydrol 403:152-175

Mishra SK, Singh VP (2010c) Soil conservation service curve number (SCS-CN) methodology. Springer, Dordrecht, p 516

Mishra AK, Sivakumar B, Singh VP (2015) Drought processes, modeling, and mitigation. Special Issue J Hydrol 526:1-302

Miyazaki T (2006) Water flow in soils. Taylor \& Francis, Boca Raton, p 418

Molley F, Wesse P (eds) (2009) River basin trajectories: societies, environments and development. IWMI-International Water Management Institute, CABI, Wallingford, p 311

Monteith JL (1965) Evaporation and the environment. In: Symposium of society of exp. biology, vol 19, pp 205-234

Monteith JL (1973) Principles of environmental physics. Elsevier, New York

Monteith JL (1981) Evaporation and surface temperature. Quart J R Meteorol Soc 107:1-27

Moramarco T, Pandolf C, Singh VP (2008a) Accuracy of kinematic wave and diffusion wave approximations for flood routing: 1. Steady analysis. J Hydrol Eng 13(11):1078-1088

Moramarco T, Pandolf C, Singh VP (2008b) Accuracy of kinematic wave and diffusion wave approximations for flood routing: 2 . Unsteady analysis. J Hydrol Eng 13(11):1089-1096

Moran PAP (1954) A probability theory of dams and storage systems. Aust J Appl Sci 5:116-124

Morris EM, Woolhiser DA (1980) Unsteady one dimensional flow over a plane: partial equilibrium and recession hydrographs. Water Resour Res 16(2):355-360

Morton Fl (1965) Potential evaporation and river basin evaporation. J Hydraul Eng 91(HY6):67-97

Morton FI (1969) Potential evaporation as a manifestation of regional evaporation. Water Resour Res 5:1244-1255

Mujumdar PP, Nagesh Kumar D (2012) Floods in a changing climate. Cambridge University Press, New York

Mulvany TJ (1850) On the use of self-registering rain and flood gauges. In: Proceedings of the Institute Civil Engineers 4(2): 1-8, Dublin, Ireland

Musgrave GW (1947) The quantitative evaluation of factors in water erosion: a first approximation. J Soil Water Conserv 2:133-138

Muskat M (1937) The flow of homogeneous fluids through porous media. McGraw-Hill, New York

Nash JE (1957) The form of the instantaneous unit hydrograph. Hydrol Sci Bull 3:114-121

Nash JE (1959) Systematic determination of unit hydrograph parameters. J Geophys Res 64(1):111-115

National Environmental Research Council (1975) Flood studies report, vol 1: hydrological studies. London, England 
Newman BD, Campbell AR, Wilcox BP (1998) Lateral subsurface flow pathways in a semiarid ponderosa pine hillslope. Water Resour Res 34:3485-3496

Nielsen DR, Biggar JW (1961) Miscible displacement in soils: 1. Experimental information. Soil Sci Soc Am Proc 25:1-5

Nielsen DR, Kirkham D, van Wijk WK (1959) Measuring water stored temporarily above the field moisture capacity. Soil Sci Soc Am Proc 23:408-412

Ouarda TBMJ (2017) Regional flood frequency modeling. Chapter 77. In: Singh VP (ed) Handbook of applied hydrology. McGraw-Hill, New York, pp 77-1-77-8

Palmer WC (1965) Meteorologic drought. U.S. Department of Commerce, Weather Bureau, Research Paper No. 45. Washington, D. C, p 58

Palmer CM (1992) Principle of contaminant hydrogeology. Lewis Publishers, Chelsea, p 211

Pandey A, Himanshu SK, Mishra SK, Singh VP (2016) Physically based soil erosion and sediment yield models revisited. CATENA 147:595-620

Panu U, Ng W (2017) Outlier analysis and infilling of missing records in hydrologic data. Chapter 16. In: Singh VP (ed) Handbook of applied hydrology. McGraw-Hill Education, New York, pp 16-1-16-7

Papanicolaou ANT, Abban B (2017) Channel erosion and sediment transport. Chapter 65. In: Singh VP (ed) Handbook of applied hydrology. McGrawHill, New York, pp 65-1-65-12

Parker G, Klingman PC, McLean DG (1982) Bed load and size distribution in paved gravel-bed streams. J Hydraul Div ASCE 108(HY4):544-571

Pathak CS, Teegavarapu R, Curtis D, Collier C (2017) Radar rainfall and operational hydrology. Special Issue J Hydrol Eng 22(5):E2017001

Penman HL (1948) Natural evaporation from open water, bare soil and grass. In: Proceedings of the royal society (London), Series A. 193: 120-145

Perumal M, Price RK (2017) Reservoir and channel routing Chapter 52. In: Singh VP (ed) Handbook of applied hydrology, pp 52-1-52-16

Pham HV, Tsai FT (2017) Groundwater modeling. Chapter 48. In: Singh VP (ed) Handbook of applied hydrology. McGraw-Hill, New York, pp 48-1-48-8

Philip JR (1957) The theory of infiltration: 1 The infiltration equation and its solution. Soil Sci 83:345-357

Pinder GF, Celia MA (2006) Subsurface hydrology. John Wiley, New York, p 468

Ponce VM, Simons DB (1977) Shallow wave propagation in open channel flow. J Hydraul Div 103(HY12):1461-1475

Poston T, Stewart I (1978) Catastrophe theory and its applications. Pitman, London, p 491

Priestley CHB, Taylor RJ (1972) On the assessment of surface heat flux and evaporation using large scale parameters. Mon Weather Rev 100:81-92

Puls LG (1928) Flood regulation of the Tennessee River. In: Proceedings of the 70th congress, Ist Session, H. D. 185, Pt. 2, Appendix B

Radcliffe D, Simunek J (2010) Soil physics with HYDRUS. CRC Press, Boca Raton, p 388

Ramette M (1980) A theoretical approach on fluvial processes. Proceedings of the International Symposium River Sediment. Beijing, China, pp C16-1-C16-17

Rao AR, Hamed KH (2000) Flood frequency analysis. CRC Press, Boca Raton, $p$ 350

Remson I, Randolf JR, Barksdale HC (1960) The zone of aeration and ground water recharge in sandy sediments at Seabrook, New Jersey. Soil Sci 89:145-156

Remson I, Hornberger GM, Molz FJ (1971) Numerical methods in Subsurface Hydrology. John Wiley, New York, p 389

Renard KG, Foster GR, Weesies GA, McCool DK, Yoder DC (1997) Predicting soil erosion by water: a guide to conservation planning with the revised universal soil loss equation (RUSLE). U.S. Department of Agriculture, Agriculture Handbook No. 703, Washington, p 404

Richards LA (1931) Capillary conduction of liquids in porous mediums. Physics 1:318-333

Richards LA (1965) Physical conditions of water in soils. In: Black CA (ed) Methods of soil analysis, monograph 9. American Society of Agronomy, Madison, pp 128-151

Richardson B (1931) Evaporation as a function of insolation. Trans Am Soc Civ Eng 95:996-1011

Rinaldi S, Soncini-Sessa R, Stehfest H, Tamura H (1979) Modeling and control of river quality. McGraw-Hill Book Publishing Company, New York

Rockwood DM (1982) Theory and practice of the SSARR model as related to analyzing and forecasting the response of hydrologic systems. In: Singh VP (ed) Applied modeling in catchment hydrology. Water Resources Publications, Littleton, pp 87-106
Rodriguez-Iturbe I, Porporato A (2004) Eco-hydrology of water-controlled ecosystems: soil moisture and plant dynamics. Cambridge University Press, Cambridge, p 442

Rodriguez-Iturbe I, Rinaldo A (2001) Fractal River Basins: Chance and SelfOrganization. Cambridge University Press, Cambridge, p 547

Rodriguez-Iturbe I, Valdes JB (1979) The geomorphologic structure of hydrologic response. Water Resour Res 15(6):1409-1420

Rodriguez-Iturbe I, Rinaldo A, Rigon R, Bras RL, Marani A, ljjasz-Vasquez EJ (1992) Energy dissipation, runoff production and the three dimensional structure of river basins. Water Resourc Res 28(4):1095-1103

Roessel BWP (1950) Hydrologic problems concerning the runoff in headwater regions. Trans Am Geophys Union 31:431-442

Rose CW, Williams JR, Sander GC, Barry DA (1983a) A mathematical model of soil erosion and deposition processes: I. Theory for a plane land element. Soil Sci Soc Am J 47(5):991-995

Rose CW, Williams JR, Sander GC, Barry DA (1983b) A mathematical model of soil erosion and deposition processes: II. Application to data from an arid-zone catchment. Soil Sci Soc Am J 47(5):996-1000

Ross TJ (2010) Fuzzy logic with engineering applications. John Wiley, New York, p 585

RZWQM Team (1992) Root zone water quality model, Version 1. Technical documentation. GPSR technical report no. 2, USDA-ARS-GPSR, Fort Collins, Colorado

Sarkar S (2017) Sedimentation of floodplains, lakes and reservoirs. Chapter 66. In: Singh VP (ed) Handbook of applied hydrology. McGraw-Hill, New York, pp. 66-1-66-10

Saverenskiy AD (1940) Metod rascheta regulirovania stoka. Gidrotekhnicheskoe Stroit'stvo 2:24-28

Scheidegger AE (1961) General theory of dispersion in porous media. J Geophys Res 66:3273-3278

Schumm SA (1956) Evolution of drainage systems and slopes in Badland $s$ at Perth Amboy, New Jersey. Geol Soc Am Bull 67:597-646

Sen Z (2010) Fuzzy logic and hydrological modeling. CRC Press, Boca Raton, p 340

Serrano SG (2017) Decomposition methods Chapter 34. In: Singh VP (ed) Handbook of applied hydrology. McGraw-Hill Education, New York, pp 34-1-34-6

Shaffer MJ, Larson WE (eds) (1987) NTRM, a soil-crop simulation model for nitrogen, tillage, and crop residue management. USDA-ARS Conservation Research Report 34-1, National Technical Information Service, Springfield, Virginia, p 104

Shen S, Leptoukh G, Fang H (2013) NASA satellite and model land data services: data access tutorial Chapter 3. In: Liang S, Li X, Xie X (eds) Land surface observation, modeling and data assimilation. World Scientific Publishing Company, Hackensack, pp 67-89

Sherman LK (1932) Stream flow from rainfall by the unit graph method. Eng News Record 108:501-505

Shields IA (1936) Application of similarity principles and turbulent research to bed-load movement (Translation from German by Ott WP, van Vchelin JC). U.S. soil conservation service cooperative laboratory. California Institute of technology, Pasadena, California, p 21

Shreve RL (1966) Statistical law of stream numbers. J Geol 74:17-37

Simons DB, Senturk F (1977) Sediment transport technology. Water Resources Publications, Littleton, Colorado, p 897

Singh VP (1988) Hydrologic systems: rainfall-runoff modeling, vol 1. Prentice hall, Englewood Cliffs

Singh VP (1989) Hydrologic systems: watershed modeling, vol 2. Prentice hall, Englewood Cliffs

Singh VP (1992) Elementary hydrology. Prentice Hall, Englewood cliffs

Singh VP (1994) Accuracy of kinematic wave and diffusion wave approximations for space independent flows. Hydrol Process 8(1):45-62

Singh VP (ed) (1995) Computer models of watershed hydrology. Water Resources Publications, Littleton

Singh VP (1996) Kinematic wave modeling in water resources: surface water hydrology. John Wiley, New York

Singh VP (1997) Kinematic wave modeling in water resources: environmental hydrology. John Wiley, New York

Singh VP (2003) On the theories of hydraulic geometries. Int J Sedim Res 18(3):196-218

Singh VP (2013) Entropy theory and its application in environmental and water engineering. John Wiley, New York, p 642 
Singh VP (2014) Entropy theory in hydraulic engineering. ASCE Press, Reston Singh VP (2015) Entropy theory in hydrologic science and engineering. McGraw-Hill Education, New York

Singh VP (2016) Introduction to tsallis entropy theory in water engineering. CRC Press/Taylor \& Francis Group, Boca Rtaon, Florida, p 434

Singh VP (ed) (2017a) Handbook of applied hydrology. McGraw-Hill Education, New York

Singh VP (2017b) Entropy theory. Chapter 31. In: Singh VP (ed) Handbook of applied hydrology. McGraw-Hill Education, New York, pp 31-1-31-8

Singh VP (2017c) Kinematic wave theory of overland flow. Water Resour Manage. https://doi.org/10.1007/s11269-017-1654-1

Singh VP, Fiorentino M (eds) (1996) Geographical information systems in hydrology. Kluwer Academic Press, Dordrecht

Singh VP, Frevert DK (eds) (2002a) Mathematical models of large watershed hydrology. Water Resources Publications, Littleton

Singh VP, Frevert DK (eds) (2002b) Mathematical model of small watershed hydrology and applications. Water Resources Publications, Littleton

Singh VP, Frevert DK (eds) (2006) Watershed models. CRC Press-Taylor and Francis, Boca Raton

Singh VP, Regl RR (1983a) Analytical solutions of kinematic equations for erosion on a plane: I. Rainfall of indefinite duration. Adv Water Resour 6:1-10

Singh VP, Regl RR (1993b) Analytical solutions of kinematic equations for erosion on a plane: II. Rainfall of finite duration. Adv Water Resour 6:88-95

Singh VP, Woolhiser DA (2002) Mathematical modeling of watershed hydrology. J Hydrol Eng 7(4):270-294

Singh VP, Yu FX (1990) Derivation of an infiltration equation using systems approach. J Irrig Drain Eng 116(6):837-858

Singh VP, Zhang L (2008a) At-a-station hydraulic geometry relations, 1: theoretical development. Hydrol Process 22:189-215

Singh VP, Zhang L (2008b) At-a-station hydraulic geometry relations, 2: calibration and testing. Hydrol Process 22:216-228

Singh VP, Zhang L (2017) Frequency distributions Chapter 21. In: Singh VP (ed) Handbook of applied hydrology. McGraw-Hill Education, New York, pp 21-1-21-11

Singh VP, Zhang L (2018) Copula-entropy theory for multivariate stochastic modeling in water engineering. Geosci Lett 5(6):17. https://doi. org/10.1186/s40562-018-0105-z

Singh VP, Bengtsson L, Westerstrom G (1997a) Kinematic wave modeling of vertical movement of snowmelt water through a snowpack. Hydrol Process 11:149-167

Singh VP, Bengtsson L, Westerstrom G (1997b) Kinematic wave modeling of saturated basal flow in a snowpack. Hydrol Process 11:177-187

Singh VP, Yang CT, Deng ZQ (2003a) Downstream hydraulic geometry relations: 1. Theoretical development. Water Resour Res 39(12):1337. https ://doi.org/10.1029/2003WR002484

Singh VP, Yang CT, Deng ZQ (2003b) Downstream hydraulic geometry relations: 2. Calibration and testing. Water Resour Res 39(12):1338. https:// doi.org/10.1029/2003WR002498

Singh VP, Jain SK, Tyagi A (2007) Risk and reliability analysis. ASCE Press, Reston, p 783

Singh VP, Singh P, Haritashya UK (2011) Encyclopedia of snow, ice and glaciers. Dordrecht, Springer

Sivakumar B (2017) Nonlinear dynamics and chaos. Chapter 29. In: Singh VP (ed) Handbook of applied hydrology. McGraw-Hill Education, New York, pp 29-1-29-11

Sivakumar B, Berndtsson R (2010) Advances in data-based approaches for hydrologic modeling and forecasting. World Scientific, Singapore, p 519

Sivakumar B, Woldemeskel FM, Singh VP (2017) Network theory Chapter 35. In: Singh VP (ed) Handbook of applied hydrology. McGraw-Hill Education, New York, pp 35-1-35-10

Smart JS, Surkan AJ (1967) The relation between mainstream length and area in drainage basins. Water Resour Res 3:963-974

Smith DD (1941) Interpretation of soil conservation data for field use. Agric Eng 22:173-175

Smith TR (1974) A derivation of the hydraulic geometry of steady-state channels from conservation principles and sediment transport laws. J Geol 82:98-104

Smith RE (1990) OPUS: an integrated simulation model for transport of nonpoint source pollutants at field scale, vol 1. Documentation. USDA-ARS Report 98, U.S. Department of Agriculture, Fort Collins, Colorado, p 120
Smith DD, Whitt DM (1948) Evaluating soil losses from filed areas. Agric Eng 29:394-398

Smith RE, Woolhiser DA (1971) Overland flow on an infiltrating surface. Water Resour Res 7(4):899-913

Smith RE, Smetten KRJ, Broadridge P, Woolhiser DA (2002) Infiltration theory for hydrologic applications. Water resources monograph 15. American Geophysical Union, Washington, D. C, p 212

Soil Conservation Service (1956) National engineering handbook, supplement A, section 4, hydrology, chapter 10. Department of Agriculture, Washington, D. C

Soil Conservation Society of America (1977) Soil erosion: prediction and control. Soil Conservation Society of America, Ankeny, p 393

Sorooshian S, Hsu K-L, Coppola E, Tomasseti B, Verdecchia M, Visconti G (eds) (2008) Hydrological modeling and the water cycle: coupling the atmospheric and hydrologic models. Springer, Dordrecht, p 291

Stebbings J (1963) The shape of self-formed model alluvial channels. In: Proceedings of the Institute Civil Engineers, London, 25: 485-510

Stedinger JR (2017) Flood frequency analysis. Chapter 76. In: Singh VP (ed) Handbook of applied hydrology. McGraw-Hill, New York, pp 76-1-76-8

Stoker JJ (1953) Numerical solution of flood prediction and river regulation problems: 1. Derivation of basic theory and formulation of numerical methods of attack. Report IMM-200, Institute of Mathematical Sciences, New York University, New York

Strahler AN (1952) Dynamic basis of geomorphology. Geol Soc Am Bull 63:923-938

Strahler AN (1957) Quantitative analysis of watershed geomorphology. Trans Am Geophys Union 38:913-920

Streeter HW, Phelps EB (1925) A study of the pollution and natural purification of the Ohio River. U.S. Public Health Bulletin, 146, February

Sveinsson OGB, Salas JD (2017) Time series analysis and models Chapter 18. In: Singh VP (ed) Handbook of applied hydrology. McGraw-Hill Education, New York, pp 18-1-18-11

Tanaka T, Yasuhara M, Sakai H, Marui A (1988) Then Hachioji experimental basin study-storm runoff processes and the mechanism of its generation. $J$ Hydrol 102:139-164

Tayfur G (2012) Soft Computing in water resources engineering: artificial neural network, fuzzy logic and genetic algorithms. WIT Press, Southampton, $\mathrm{p} 267$

Tayfur G, Singh VP (2017) Artificial neural networks Chapter 11. In: Singh VP (ed) Handbook of applied hydrology. McGraw-Hill Education, New York, pp 11-1-11-6

Taylor Gl (1953) Dispersion of soluble matter in solvent flow flowing slowly through a tube. Proc R Soc London Series A 219:186-203

Taylor Gl (1954) The dispersion of matter in turbulent flow through a pipe. Proc $R$ Soc London Series A 223:446-468

Tchobanoglous G, Schroeder ED (1985) Water quality: characteristics, modeling, and modification. Addison-Wesley Publishing Company, Reading, p 768

Theis CV (1935) The relation between the lowering of the piezometric surface and the rate and duration of discharge of a well using ground-water storage. Trans Am Geophys Union 16:519-524

Thomann RV (1972) Systems analysis and water quality management. McGraw-Hill Book Company, New York, p 286

Thomann RV, Mueller JA (1987) Principles of surface water quality modeling and control. Harper \& Row, Publishers, New York, p 644

Thomas HA Jr, Fiering MB (1962) Mathematical synthesis of streamflow sequences for analysis of river basins by simulation. In: Mass A et al (eds) The design of water resources systems. Harvard University Press, Cambridge, pp 459-493

Thornthwaite CW (1948) An approach toward a rational classification of climate. Geogr Rev 38:55-94

Todd DK (1980) Ground water hydrology. John Wiley, New York

Todini E (2017) Predictive uncertainty assessment and decision making Chapter 25. In: Singh VP (ed) Handbook of applied hydrology. McGraw-Hill Education, New York, pp 25-1-25-16

Todini E, Biondi D (2017) Calibration, parameter estimation, uncertainty, data assimilation, sensitivity analysis, and validation Chapter 22. In: Singh VP (ed) Handbook of applied hydrology. McGraw-Hill Education, New York, pp 22-1-22-19

Todorovic P (1978) Stochastic models of floods. Water Resour Res 14(2):345-356 
Tripathi S, Govindaraju RS (2017) Relevance vector machines. Chapter 14. In: Singh VP (ed) Handbook of applied hydrology. McGraw-Hill Education, New York, pp 14-1-14-7

Tung Y, Mays LW (2017) Risk-reliability analysis Chapter 27. In: Singh VP (ed) Handbook of applied hydrology. McGraw-Hill Education, New York, pp 27-1-27-10

Tung Y-K, Yen BC (2005) Hydrosystems engineering uncertainty analysis. McGraw-Hill, New York, p 273

Turner LB (1967) Abstraction of depression storage from storms on small impervious areas. Unpublished M.S. Thesis, University of Maine, Orono, Maine

Ullah W, Dickinson WT (1979a) Quantitative description of depression storage model using a digital surface model: I. Determination of depression storage. J Hydrol 42:63-75

Ullah W, Dickinson WT (1979b) Quantitative description of depression storage model using a digital surface model: II. Characteristics of surface depressions. J Hydrol 42:77-99

U.S. Army Corps of Engineers (1936) Method of flow routing. Report on survey for flood control, Connecticut River Valley, vol 1, section 1, Appendix, Providence, Rhode Island

U.S. Army Corps of Engineers (1956) Snow hydrology. Summary report of the snow investigations. North Pacific Division, Portland, Oregon

Valencia RD, Schaake JC Jr (1972) Disaggregation processes in stochastic hydrology. Water Resour Res 9(3):291-295

Vanoni V (ed) (1975) Sedimentation engineering. ASCE manuals and reports on engineering practice no. 54. American Society of Civil Engineers, New York, (now Reston, Virginia), p 745

St. Venant de B (1871) Theory of unsteady water flow, with application to river floods and to propagation of tides in river channels. French Academy of Science, vol 73, pp 148-154, 237-240

Veneziano D, Lepore C (2017) Scaling and fractals Chapter 28. In: Singh VP (ed) Handbook of applied hydrology. McGraw-Hill Education, New York, pp 28-1-28-6

Vogel RM, Castellarin A (2017) Risk, reliability, and return periods and hydrologic design. Chapter 78. In: Singh VP (ed) Handbook of applied hydrology. McGraw-Hill, New York, pp 78-1-78-10

Voss Cl, Provost AM (2002) SUTRA, a model for saturated-unsaturated variable density groundwater flow with energy or solute transport. U.S. Geological Survey Water Resources Investigations Report 2002-4231. Reston, Virginia, p 291

Wagner T, Wheater HS, Gupta HV (2004) Rainfall-runoff modelling in gauged and ungauged catchments. Imperial College Press, London, p 306

Weibull W (1939) The phenomenon of rupture in solids. Ingeniors Vertenskaps Akademien Handlinga 153:17

White WR, Bettess R, Paris E (1982) Analytical approach to river regime. J Hydraul Div Proc ASCE 108(HY10):1179-1193
Wischmeier WH, Smith DD (1957) Factors affecting sheet and rill erosion. Trans Am Geophys Union 38:889-896

Wischmeier WH, Smith DD (1965) Predicting rainfall-erosion losses from cropland east of the Rocky Mountains: guide for selection of practices for soil and water conservation. Department of Agriculture (USDA) Agriculture Handbook, Washington, p 282

Wischmeier WH, Smith DD (1978) Predicting rainfall erosion losses: a guide to conservation planning. Department of Agriculture (USDA) Agriculture Handbook, Washington, p 537

WMO (World Meteorological Organization) (1986) Report on drought and countries affected by drought during 1974-1985. WMO, Geneva, p 118

Wolman MG (1955) The natural channel of Brandywine Creek, Pennsylvania. U.S. Geological Survey Professional Paper 271, Washington, D. C

Woolhiser DA, Liggett JA (1967) Unsteady one-dimensional flow over a plane: the rising hydrograph. Water Resour Res 3(3):753-771

Yalin MS, Da Silva AMF (1997) On the computation of equilibrium channels in cohesionless alluvium. J Hydrosci Hydraul Eng 15(2):1-13

Yalin MS, Da Siva AMF (1999) Regime channels in cohesionless alluvium. J Hydraul Res 37(6):725-742

Yang CT (1971) Potential energy and stream morphology. Water Resour Res 7(2):311-322

Yang CT (1972) Unit stream power and sediment transport. J Hydraul Div ASCE 18(HY10):1805-1826

Yang CT, Song CCS (1986) Theory of minimum energy and energy dissipation rate, Chapter 11. In: Cheremisinoff NP (ed) Encyclopedia of fluid mechanics, Gulf Publish. Company, Houston

Yevjevich V (1972) Stochastic processes in hydrology. Water Resources Publications, Highlands Ranch, p 276

Yotsukura N (1977) Derivation of solute-transport equation for a turbulent natural-channel flow. J Res US Geol Survey 5(3):277-284

Yotsukura N, Sayre WN (1976) Transverse mixing in natural channels. Water Resour Res 12(4):695-704

Young P (2017) Data-based mechanistic modeling Chapter 33. In: Singh VP (ed) Handbook of applied hydrology. McGraw-Hill Education, New York, pp 33-1-33-12

Zamani K, Bombardelli FA (2014) Analytical solutions of nonlinear and variableparameter transport equations for verification of numerical solvers. Environ Fluid Mech 14:71-742

Zamani K, Ginn TR (2017) Pollutant transport in vadose zone Chapter 68. In: Singh VP (ed) Handbook of applied hydrology. McGraw-Hill Education, New York, pp 68-1-68-8

Zeeman EC (1978) Catastrophe theory. Addison Wesley, Boston, p 674

Zingg AW (1940) Degree and length of land slope as it affects soil loss in runoff. Agric Eng 21:59-64

\section{Submit your manuscript to a SpringerOpen ${ }^{\circ}$ journal and benefit from:}

- Convenient online submission

- Rigorous peer review

- Open access: articles freely available online

- High visibility within the field

- Retaining the copyright to your article

Submit your next manuscript at $\boldsymbol{\nabla}$ springeropen.com 